\title{
Aklın İmkânı ve Sınırı: Fahreddin Râzî'ye Göre Genel ve Özel Metafizik Bilginin İmkânı
}

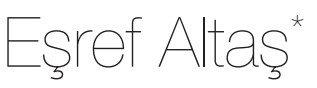

\section{Özet}

Bu makalede Râzînnin metafizik bilginin imkânı hakkındaki görüşleri incelendi. Öncelikle Râzînnin metafizik bilinenleri, zat ve varlık, genel (icmâlî) ve ayrıntılı (tafsîlî) bilinenler şeklinde bölümlemesi betimlendi. Râzînin genel metafizik bilgiyi mümkün gördüğü birkaç başlık altında incelendi. Bu başlıklar altında varlık kümesinin duyulur âlemden daha geniş olduğu, teorik düşüncenin metafizik bilgi verdiği, nazarî delillerin bir yaratıcının varlığı hakkında zorunlu bilgi verdiği iddiaları ele alındı. Râzînin, erken dönemde yazdığı eserlerde mühendisiyyûn dediği bir gruba atfettiği metafizik bilginin inkârının delillerini, el-Metâlib'de ancak Tanrı'nın zatının bilinmesi konusuna hasrederek tevarüs ettiği gösterildi. Nazarın Râzîye göre özel metafizik bir mevcudun varlığı hakkında bilgi verdiği ama mahiyeti hakkında bilgi vermeyeceği anlatıldı. Tanrı'nın zatının bilinemeyeceği görüşünün metafizik ve epistemolojik tezlerine dikkat çekildi ve bu görüşün semantik yorumu tartışıldı. Nazar metodunun ayrıntılı (tafsîlî) metafizik hakkında, ancak en uygun açıklama tarzında kesinlik içermeyen bir bilgi verebileceği (evleviyet metafiziği) tartışması ise başka bir makaleye bırakıldı.

Anahtar Kelimeler: Fahreddin er-Râzî, metafizik, Tanrı'nın zatı, Tanrı’nın varlığı, icmâlî metafizik.

\begin{abstract}
This article examines al-Rāzì's views on the possibility of metaphysical knowledge. After outlining first his classification of the metaphysical knowable into essence and existence, and general (ijmālì) and detailed (tafșìlì), it analyzes al-Rāzī's acceptance of the possibility of general knowledge of metaphysics under a few headings by delving into some major themes. These include the claims that the category of existence is broader than the world of the sensible, the theoretical reasoning leads to metaphysical knowledge, and, lastly, that the theoretical evidence provides necessary knowledge about the existence of a creator.

It has also been demonstrated that in al-Mațālib al-Rāzī inherited the arguments for the rejection of metaphysical knowledge, which he had attributed to a group with the name muhandisiyyūn in his earlier works, by restricting them to the issue of the knowability of the essence of God. For al-Rāzī, theoretical reasoning could provide knowledge about the existence of a particular metaphysical being but not about its quiddity. The article further underlines the metaphysical and epistemic theses for the position on the unknowability of God's essence and discusses its semantic interpretation. The debate on the potential of theoretical reason to provide uncertain knowledge of detailed metaphysics in the form of best possible explanations (the metaphysics of the best explanation: al-awlawiyya), however, is left to another article.
\end{abstract}

Key words: al-Rāzī, metaphysics, negative theology, God's essence, God's existence.

* Doç. Dr., İstanbul Medeniyet Üniversitesi, Edebiyat Fakültesi, Felsefe Bölümü, İslam Felsefesi Anabilim Dalı. İletişim: esrefaltas@gmail.com 


\section{Giriş}

Aklın metafizik bilgiye ulaşma imkânı ve sınırı, İslam düşünce tarihinin temel tartışma konularından biridir. Bu tartışmaların tarafları kaynaklarda bazen belirli isimler, bazen de sofistler ve mühendisiyyûn gibi müntesipleri açık olmayan gruplar olarak belirtilir. Klasik dönemde telif edilmiş kelâm ve felsefe metinlerindeki anlatıya göre bilgiyi tümüyle reddeden sofistler, doğal olarak metafizik bilgiyi de reddetmişlerdir. Sümeniyye sadece duyunun bilgi verdiğini iddia ettiğinden rasyonel bilgiyi, buna bağl1 olarak da aklın metafizik bilgiye ulaşma imkânını reddetmiştir. Mühendisiyyûn ise insanın sadece matematik alanda bilgi elde edebileceğini iddia etmişler, metafizik bilginin imkânını duyulur alanın bilgisine kıyas ederek duyularla doğrudan idrak edilen bilgilerin dahi tam ve kesin olmamasını spekülatif olan metafizik alanla ilgili bilginin imkânsızlığına örnek göstermişlerdir. Sûfîler ise akıl yürütmenin güvenilmezliğini, akıl yürütme yanlışlarını ve göreliliğini akılla metafizik bilgi edinmenin zorluğuna veya imkânsızlığına yormuşlar ve metafizik alanda ancak vahiy tecrübesine benzer bir müşahedeyle bilgiyi mümkün görmüşlerdir.

Bu makalede sofistlerin bilginin imkânıyla ilgili eleştirilerine değinilmeyecek, diğer grupların metafizik bilgiye yönelik şüpheleri ise kısaca ele alınıp Râzînin cevapları verilecektir. Ancak makale, bu grupların eleştirilerini ve bu eleştirilerin cevaplarını, Râzînin, genel metafizik bilginin imkânına ve özel metafizik varlığın bilgisine yönelik görüşünü ortaya koymakta bir aracı olarak kullanmak arzusundadır. $\mathrm{Bu}$ nedenle makalenin amac1, nazar yönteminin metafizik bilgiyle ilgili iddiasının gücünü Râzî örneğinde göstermek ve özellikle sûfî geleneğin "Râzî̉nin ulaştığı nokta, aklî metafiziğin yetersizliğinin delilidir" şeklindeki iddialarının, ${ }^{1}$ Râzî̀nin bizzat kendisindeki durumunu ortaya çıkarmaktır. Bu durumda makalenin odak noktası, Râzînnin görüşüne göre nazarın, genel ve özel metafizikle ilgili bilgiye ulaştırma gücü, yeterliliği, yetkinliğidir.

Râzî öncelikle metafizik malumları, varlık-mahiyet, zatî-arazî ve zat-sıfat-fiil ikiliklerinden hareket ederek şu kısımlara ayırır:

a. Genel metafizik varlık alanını bilmek.

b. Özel metafizik varlığın, yani Tanrı'nın varlı̆̆ını bilmek.

1 Bu anlayış özellikle Mevlânâ'nın şu beyitlerinde karakterize edilmiştir: "Eğer akıl bu yolda kılavuzluk edebilseydi / Fahr-i Râzî, dinin (ince) bilgilerinin bilicisi olurdu / Çünkü 'tatmayan bilmez', bu yüzden / Onun akh ve hayalleri sadece hayretini artırdı / Bu 'ben', nerde düşünceylekeşfolacak? / O ‘ben', fenadan sonra keşfolur.” Mevlânâ Celâlüddîn Muhammed b. Muhammed el-Belhî, Mesnevî, çev. Veled İzbudak (İstanbul: MEB Yayınları, 1988), V, 337; Ayrıca bk. Hayri Kaplan, “Bahâ Veled, Şems ve Mevlânâ’nın Râzîye Eleştirileri ve Râzî’nin Sûfîlere/Tasavvufa Bakışı”, Tasavvuf İlmî ve Akademik Araştırma Dergisi 6/14 (2005): 285-330. 
c. Tanrı'nın özel zatını (ez-zâtü'l-mahsûsa), hakikatini ve İbn Sînâcı çerçevede Tanrı'nın bir mahiyete sahip olup olmadığını bilmek.

d. Tanrı'nın olumsuz sıfatlarını bilmek.

e. Tanrı'nın olumlu sıfatlarını bilmek.

f. Tanrı'nın isimlerini bilmek.

g. Tanrı'nın fiillerini bilmek. ${ }^{2}$

Buna göre mutlak olarak kullanıldığında metafizik bilgi ile bu malumların tamamının genel veya ayrıntılı bilgisini, ya da özel birinin genel ve ayrıntılı bilgisini kastedebiliriz. Bu makalede yukarıda belirlenen amaçları gerçekleştirmek için ilk üç şıkkın ayrıntılarına odaklanacağız. Öncelikle Râzînin genel metafizik alanın genel tarzda bir bilgisinin (alâ sebîli’l-icmâl) imkânı konusundaki olumlu yaklaşımını, ardından özel metafizik varlı̆̆ın genel tarzda bir bilgisinin (alâ sebîli'l-icmâl) ispatıyla ilgili olumlu yaklaşımını, nihayet bu özel metafizik varlığın ayrıntılı bir tarzda bilinmesine (alâ sebîli't-tafsîl), yani Tanrı'nın zatının bilinmesine yönelik olumsuz yaklaşımı incelenecektir. Böylece Râzînnin metafizik malumları bilmekle ilgili iddialarının, icâbî dilden selbî dile, varlık bilgisini ifade eden icmâlî bir tarzdan mahiyet bilgisini ifade eden tafsîlî bilgiye, kesinlik ifade eden yakînden zan ifade eden evleviyete kadar geniş bir yelpazeyi taradığı gösterilmeye çalışılacaktır.

\section{Genel Metafizik Alanın Genel (İcmâlî) Bilgisinin İmkânı}

Râzînnin genel metafizik âlemin genel olarak (alâ sebîli'l-icmâl), yani varlığının bilinmesiyle ilgili görüşlerini şu iki ana başlık etrafında ele alacağız: (a) Genel metafizik alan hakkında vehmin ve hayalin hükmü. (b) Nazarın metafizik bilgi vermediği iddiası ve eleştirisi.

\section{(a) Vehim ve Hayalin Genel Metafizik Alanla İlgili Hükmü}

İslam düşünce tarihinde Mücessime, Müşebbihe, Kerrâmiyye gibi çeşitli gruplar Tanrı'nın varlığını kabul etmekle birlikte Tanrı da dâhil, mekân ve yönü aşan soyut metafizik varlık alanı kabul etmezler. ${ }^{3}$ Sümeniyye ise duyu idrakleri dışında bir bilgiye sahip olmadığımızı iddia ederek aklı araç haline getirir ve böylece nazarın, tümel

2 Fahreddin er-Râzî, el-Metâlibü'l-âliye mine'l-ilmi'l-ilâhî, thk. Ahmed Hicâzî es-Sekkâ (Beyrut: Dâru'l-Kitâbi'l-Arabî, 1407/1987), II, 88-9.

3 Râzî, el-Metâlib, II, 9 vd.; Fahreddin er-Râzî, Allah'in Aşkınlığı: Esâsu't-takdîs fî ilmi'l-kelâm, çev. İbrahim Coşkun (İstanbul: İz Yayıncılık, 2006), 38-9. 
bir varlık anlamına ulaştırmadığını ve metafizik alanın bilgisini vermediğini söyler. Buna karşılık İslam düşünce geleneğinin büyük bir kısmı yön, cihet, cisim ve cismani olanın ötesinde, duyulur alanın ötesinde bir metafizik varlık alanı olduğunu ve aklın bu alanın bilgisini verdiğini iddia edegelmiştir. Örneğin Sümeniyye'den bir grubun beş duyuyu tek tek sayarak "Beş duyuyla algılamadığın halde nasıl oluyor da bir ilah olduğunu biliyorsun?” şeklindeki sorusuna Cehm b. Safvân, duyu algılarının ruh örneğinde olduğu gibi bütün varlık alanını kuşatamadığını söyleyerek cevap vermiştir. ${ }^{4}$

İbn Sînâ'yı yorumlarken Râzî, metafizik âlemin varlığını, mevcut kümesinin duyulur kümesinden daha geniş olduğu düşüncesinin ispatına bağlar. İbn Sînâ'ya göre genel olarak insanlar, vehim gücüyle, "Mevcut, duyulur olandan (el-mahsûs) ibarettir" hükmünü verirler; başka bir ifadeyle mevcut kümesini duyulur kümesine eşit olarak görürler. Epistemolojik açıdan bakıldığında vehmin bu hükmü, hem duyusal olan vehmin bizatihi kendi sınırının dışına çıkması anlamına gelir hem de insan aklının duyusal alanı aşamayacağı üzerine yanıltıcı bir hükümdür. Râzînin ontolojik açıdan ifadesiyle "Oysa duyulur hakkında düşündüğünde anlarsın ki, duyulur olanın kendisinde duyulur olmayan şeyler vardır". ${ }^{6}$ İbn Sînâ da daha önce buna benzer bir görüş ifade ettikten sonra "Bu, oldukça şaşırtıcıdır" der. ${ }^{7}$ Epistemolojik açıdan söylersek duyu ve hayalin bilgisi, duyu ve hayal gücünün bizatihi kendisinden daha fazla bir şeydir. ${ }^{8}$ Çünkü bakışını bütünüyle fizik dünyaya hasrettiğini düşünenlerin perspektifinde dahi fiziksel dünyaya ait duyu tecrübesinde ortaya çıkan unsurlar, bizzat o duyu tecrübesinin inşasını veremez, bu tecrübeyle elde edilen duyu bilgisi duyuda inşa edilemez, bu nedenle vehmin hükmüne ihtiyaç duyar. Örneğin, insanın el, ayak, kafa, gövde vb. parçalarının tecrübedeki toplamı insanı vermemektedir. “Tümel insan" anlamı, maddeden ve maddî ilgilerin tamamından soyut olmak itibariyle duyulur olmayan bir şeydir. Râzî tümelin sadece zihinde kabul edilmesi durumunda zihnî anlamları kabul eden, ama dışta metafizik varlıkları kabul etmeyenlere bir cevap olamayacağından hareketle, tümelin dişta varlığının kabul edilmesinin gerçekte metafiziğe kapı açacağını düşünmektedir. Râzî bu temellendirmesini şöyle yapar: "Bu insan" işareti dişta bileşik bir varlığı gösterir ve bu bileşiğin basit parçaları, yani "bu" işareti ve bu işaretin konusu olan "mutlak insan" dişta mevcuttur. Bu demektir ki “bir şey şartıyla olmayan” insan mahiyeti dışta mevcuttur. Mutlak insan mahiyeti,

4 Ahmet b. Hanbel, er-Red 'ale'l-Cehmiyye ve'z-Zenâdika, thk. Sabrî Selâme Şahin (Riyad: Dâru's-Sebât, 1424), 93-5.

5 İbn Sînâ, el-İşârât ve't-tenbîhât, Fahreddin er-Râzî, Şerhu'l-İ̧̧ârât ve't-tenbîhât, thk. Ali Rıza Necefzâde (Tahran: Encümen-i Âsâr ve Mefâhir-i Ferhengî, 1384) ile birlikte, II, 336.

6 Râzî, Şerhu'l-İşârât, II, 337.

7 İbn Sînâ, el-i̇şârât, II, 336.

8 Râzî, el-Metâlib, II, 17. 
"bu" işaret sıfatıyla işaret edilmediği veya maddi ilişenler eklenmediği müddetçe duyulur değildir. O halde "duyulur olmayan" en az bir mevcut vardır. ${ }^{9}$

Soru olarak ifade edecek olursak daima bir nesnenin parçalarıyla karşılaştığ1mız halde nasıl oluyor da biz onu var olarak, üstelik bir şey olarak, dahası kendinde ayrışmış, taayyün etmiş ve cevheri birliğe kavuşmuş bir şey olarak kavrıyoruz? Yine daima tikel nesneyle karşılaştığımız halde nasıl oluyor da biz tikel nesnelerin bütün fertlerinin kendi kapsamına girmesini engellemeyecek ve nesnenin yerini tutan cevherî birliğe sahip bir tümele ulaşabiliyoruz? İşaretle ayrıştırılabilen tikeli kavramak ve tikellerini kapsayan tümeli kavramak nihai olarak duyu tecrübesinde ortaya çıan şeyin dışına çlkmak ve onu genişletmek, böylece tümel aracılığıyla fizik dünyanın ötesinde başka bir varlık katmanına işaret etmek demektir. ${ }^{10}$

İbn Sînâ bu çerçevede önemli bir noktaya daha temas etmektedir: "Her hak, kendisinin, kendisiyle hak olduğu zatî hakikati bakımından, işaret edilemeyen tek bir birliktir. Öyleyse her hakkın kendi varlığına, kendisiyle ulaştığı şey nasıldır?" Râzî bu ifadeleri şöyle yorumlar: İnsan, dışta var olan bir şeyin kendisine ilişmiş bireyselleştiren özelliklerini soyutlarsa onun duyulur olmadığını anlar. Çünkü dıştaki herhangi bir nesneyi belli bir sınırla, belli bir tanımla sınırlamak ve ona işaret etmek ancak onu kendisi dışındaki nesnelerden ayırt etmeyi mümkün kılan hakikatiyledir. Nesnenin dışta var olmasının ve ayrışmasının sebebi uzam, renk, sertlik, yön vs. gibi duyulur özellikleri değil, esasen onu var kılan hakikatidir. Dışta varlığı ve inniyeti olan bir şey, mutlak varlık ve mutlak cisim olarak değil, daima mahiyeti olan bir şey olarak, bir hakikat olarak var olur. Sonuç olarak kendisine dışta işaret edilebilir olmayan, yani duyulur olmayan bu hakikati dışta var kılan Hakk'ın, duyuyu aşan bir varlığa sahip olması daha uygundur. ${ }^{11}$ Çünkü "hakikat" ifadesi, Tanrı için kullanıldığında "mümkünlere hakikatini veren" şeklinde fail anlamındadır. Mümkünler için ise meful anlamındadır. Çünkü mümkünler ancak Hakk’n hakikat vermesiyle hakikate sahip olur. ${ }^{12}$

Râzî metafizik alanın varlığını ispat ederken zaman, mekân, boşluk ve idealar gibi Platoncu fiziksel olmayan kaim varlıkların da -kabul edilmeleri halinde- birer delil olabileceğini belirtir. İlaveten Râzî, filozofların nefis ve akılları mücerret olarak

10 Râzî, Şerhu'l-İşârât, II, 337-9; el-Metâlib, II, 17. Kaba materyalizmin reddi bağlamında İbn Sînâ aşk, korku, hüzün vb. duyguların da bedendeki infial süreçlerine indirgenemeyeceğini ve bu nedenle duyulur olmadığını, dolayısıyla metafizik alana işaret edebileceğini söyler. İbn Sînâ, el-İşârât, II, 339.

11 Râzî, Şerhu'l-İşârât, II, 339-40.

12 Râzî, el-Metâlib, III, 246. Bu temellendirmelerin dişın gerçekliğini kabul eden bir ontolojik zeminden hareket ettiği hatırda tutulmalıdır. 
kabul etmesinin de -kabul edilmeleri halinde- metafizik varlık alanına bir işaret olduğunu söyler. ${ }^{13}$

Özetle Râzî̀ye göre "Mevcut, duyulur olandan ibarettir" hükmü aklın değil, vehmin hükmüdür ve yanlıştır. Çünkü hem ontolojik olarak duyulur nesne, duyulur olandan daha fazla bir şeydir hem epistemolojik olarak duyu bilgisinin bizatihi kendisi duyuyu aşan bir bilgidir hem de vehmin verdiği bu hükmün bizatihi kendisi vehmin hüküm alanının dışında olduğundan kendi içinde çelişiktir. Tümel, ide vb. duyu algısının yakalayamadığı varlıklar -eğer varsalar- dıştadır. O halde duyu algısının algıladığı duyulur dünyanın dışında metafizik bir âlem vardır. Sonuç olarak varlık kümesi duyulur kümesinden daha geniştir.

\section{(b) Nazarın Metafizik Bilgi Vermediği İddiası ve Eleştirisi}

Râzî birçok kitabında, sofistlerin "bilginin imkânı"na, Sümeniyye’nin "rasyonel bilginin imkânı"na ve mühendisiyyûnun ve Bâtınîlerin (ehl-i ta'lîm) "metafizik rasyonel bilginin imkânı"yla ilgili olumsuz görüşlerini ayrıntılı olarak inceler. Esasında metafizik bilginin imkânına yönelik bu eleştirilerin bir kısmı her türlü idrakimizin güvenilmez olduğunu söylerken, ikinci kısmı duyulardan gelen idrakleri temel alarak aklın bu zemin üzerine inşa edildiğini ve bunların organizasyonunu yapan bir araca dönüştüğünü ifade eder. Üçüncü bir kısmı ise metafizik bir tasavvurun hiçbir şekilde duyu, vicdan (fıtrat), akılda içerilmediğine, yani insanın metafizik alana dair herhangi bir bilgi aktının olmadığına dikkat çeker. Biz bu başlık altında konumuzla ilgili olarak bu grupların sadece nazarın metafizik bilgi vermeyeceğiyle ilgili delillerine kısaca işaret edeceğiz, ardından Râzî’nin eleştirileri ve çözümünü belirteceğiz.

Râzî̀ye göre "metafizik bilginin imkânsızlı̆̆ı" hakkındaki görüşün birinci delili -ki Bâtınîlerin de masum imam teorisini ispat etmek için kullandıkları delilin aynıdırmetafizik görüşlerin birbiriyle çelişmesidir. Buna göre insanlar farklı metafizik görüşler savunmaktadır, hatta bir insan ferdi bile hayatı boyunca farklı metafizik görüşlere sahip olabilmektedir. Bu görüşlere nazar yoluyla varıldığına göre bu demektir ki, nazarın metafizik hakkında verdiği bilgiler zan ve tahminden ibarettir. ${ }^{14}$ İkinci delil, insanın duyu, vicdan, akıl ve bunların terkibinden kavramlar elde edebileceğini, oysa bunların hiçbirinin metafizik bir kavrama kaynaklık edemeyeceğidir. Üçüncü delil ise insanın, kendi ontolojik düzleminde bulunan cisim, zaman, mekân gibi hakikatleri

14 Fahreddin er-Râzî, Nihâyetü'l-ukûl fî dirâyeti'l-usûl, thk. Said Abdüllatif Fûde (Beyrut: Dâru'z-Zehâir, 2015/1436), I, 182; Fahreddin er-Râzî, el-Metâlibü'l-âliye: el-Mantık, Süleymaniye Kütüphanesi, Fatih 3145, vr. 55a. 
kavrayamamasıdır. İnsan kendisinin bile ne olduğunu bilmekten acizken metafizik hakikatleri nasıl bilebilir? Bir başka ifadeyle nazar tabiî alan hakkında bize kesin bir bilgi vermezken, spekülatif bir alan olan metafizik hakkında bilgi nasıl verebilir? ${ }^{15} \mathrm{Bu}$ son iki delil ayrıntılı olarak aşağıda zât-ı mahsûsayla ilgili kısımda ele alınacağından burada bu delillerin cevabına odaklanalım.

Râzî̀nin bu delillere karşı cevabı iki yönlüdür. Râzîye göre "Bu deliller, metafizik bilginin imkânsızlığını değil, sadece zorluğunu belirtir."16 Çünkü (i) insanlar mahiyet bakımından farklı olduklarından, böylece farklı meleke ve idrak kapasitelerine sahip olduklarından, (ii) metafizik bilginin mertebeleri ve türleri farklı olduğundan ve böylece perdeler katmanlı olduğundan, (iii) metafizik bilginin test edilmesinin zorluğu sebebiyle mugalata, aldanma ve yanılmalar çok olduğundan ${ }^{17}$ bütün insanların kendisine katılabileceği standart bir metafizik biliminin inşa edilmesi söz konusu olmayabilir.

Ayrıca bu deliller el-Metâlib’in baş kısmında belirtildiği üzere genel metafizik alanın varlığı hakkında değil, sadece yaratıcının özel hakikatinin bilinememesi konusunda geçerlidir. O halde Râzî erken dönem eserlerinden itibaren dile getirdiği ve el-Metâlib'in baş kısmında içselleştirerek anlattığı metafizik bilginin imkânsızlığı hakkında mühendisiyyûn denilen grubun görüşünü ve delillerini tevarüs eder, ancak delilleriyle birlikte bu görüşü, sadece zât-ı mahsûsanın hakikatinin bilinmesi konusunda geçerli olacak şekilde sınırlar. Buradan çıkarılacak sonuç ise zat ve hakikat hakkında bilginin imkânsız olduğudur, yoksa genel metafizik alanın bilgisinin tümüyle imkânsız olduğu değildir.

Peki böyle bir varlık alanında özel bir varlığın bilgisini hangi yöntemle elde ederiz, bu yöntemin bilgi verme keyfiyeti nedir ve bu bilginin kesinliği hakkında ne söyleyebiliriz?

\section{II. Özel Metafizik Varlığın Genel (İcmâlî) Bilgisinin İmkânı}

Râzînin özel metafiziğin varlığının bilgisinin imkânıyla ilgili görüşlerini üç başlık altında ele almak mümkündür: (a) Özel metafizik varlığın ispatının yolu. (b) Nazarın özel metafizik mevcut hakkında verdiği bilginin mahiyet bilgisi değil, varlık bilgisi olduğu.

(c) Nazarın özel metafizik mevcut hakkında verdiği varlık bilgisinin yakînî olduğu.

16 Râzî, el-Muhassal, 38 [أن ما ذكرتموه يدل على صعوبة تحصيل هذا العلم، لا على تعذره].8

17 Râzî, el-Metâlib, I, 55-9. 


\section{(a) Özel metafizik varlığın ispatının yolu}

Râzîye göre şu yollar ya yaratıcının varlığını bize bildirmez ya da güvenilir bilgi vermez: (i) Yaratıcının varlı̆̆ının bilgisi Câhız’ın ya da Ka'bînnin söylediği gibi zorunluluk yoluyla değildir; yani yaratıcının varlığı zorunlu olarak bilinemez; çünkü bu, hem tecrübeye hem dinî teklife aykırıdır. (ii) Yaratıının varlığının bilgisine insanın gelenek, telkin veya taklit yoluyla ulaştığı söylenebilirse de, taklit büyük kelâmî geleneklerin icmâsıyla yaratıcının varlığının bilinmesi konusunda yeterli değildir. (iii) Yaratıcının varlığının bilgisinin Ta'lîmiyye ve Haşeviyye'nin söylediği gibi naklî delille elde edilmesi de kısırdöngü içermesi sebebiyle mümkün değildir. (iv) Yaratıcının varlığının bilgisini mütevatir haber de veremez; çünkü mütevatir haber, köken itibariyle duyuya dayanmalıdır, ama Tanrı'nın varlığının bilgisi duyusal değildir. Âhâd haber ise zan ifade eder ve yakînî katî delilleri gerektiren itikadi konularda zanna tutunmak söz konusu olamaz. ${ }^{18}(\mathrm{v})$ Yaratıcının varlığının bilgisinin ilham yoluyla elde edilmesi kelâm içerisinde marjinal kalmış bir görüşe ve Hintlilere dayandırılır. (vi) İnsanın kalbini temizlemesi (tasfiye) yoluyla yaratıcının varlığının bilgisine ulaşması ise hatadan emin olunamaması ve nihayetinde nazara ihtiyaç duyması sebebiyle yeterli ve güvenilir bir yol değildir. (vii) Bâtınîlerin savunduğu masum bir imamın özel varlığı öğretmesi (ta'lîm) yolu ise nazarın bilgi verdiğine yönelik eleştirilere dayanması sebebiyle temelde sofist bir tutumdur; ilaveten bu konuda bilgi verdiği iddia edilen muallimin masumiyetinin de bir garantisi yoktur. (viii) Yaratıcının varlı̆̆ının bilgisinin duyu yoluyla elde edilmesi de metafiziğin duyuları aşan doğası gereği mümkün değildir. (ix) Yaratıcının varlığının bilgisi, insanın doğuştan getirdiği fıtrî yapısında ve vicdanında bulunan psikolojik bir ide de değildir. (x) Yaratıcının varlığının bilgisi, aklımızda bulduğumuz varlık, yokluk, birlik gibi ikinci makuller tarzında bir tasavvur da değildir. ${ }^{19}$

Nitekim Râzî yaratıcının varlığının ispatına şöyle başlar:

Bil ki biz eğer duyularımızın varlığına hükmetmediği, nefsimiz ve aklımızın doğuştan sahip olduğu yapısının (fitrat) da varlığına hükmetmediği bir mevcudu [yani yaratıcıyı] ispat etmek istiyorsak böyle bir mevcudun ispatına götüren ancak tek bir yol vardır. $\mathrm{Bu}$ yol, sarih aklımızın, duyu ve aklımızla var olduğuna hükmettiğimiz bu duyulur mevcutların, ya varlıkları ya da sıfatları bakımından duyu ve vehimlerimizin ulaşamadığı bir mevcudun varlığına muhtaç olduğuna hükmetmesidir. Ancak bu yolla akıl, o metafizik (el-gâib) varlığın ispatına güç yetirebilir. ${ }^{20}$

19 Ayrıntılar için bk. Râzî, el-Metâlib, I, 207; Râzî, el-Muhassal, s. 36-40; Râzî, Nihâyetü'l-ukûl, I, 195-219; Râzî, er-Riyâzü'l-mûnika fî ârâi ehli'l-ilm, nşr. Es'ad Cum'a (Tunus: Merkezü'n-neşri'l-câmiî, 2004), 59-69; Necmettin Ali b. Ömer el-Kâtibî, el-Mufassal, thk. Abdülcabbâr Ebû Senîne (Amman: el-Asleyn li'd-dirâsât ve'n-neşr, 2018/1439), I, 149-59. 
Şimdi özel metafizik varlığın bilgisi zorunluluğa, telkine, taklide, nakli delile, mütevatir veya âhâd habere, ilhama, talim öğretisine, eksik tasfiyeye, duyulara dayanmıyorsa, nefiste doğuştan getirilmiyorsa, akılda da bedîhî olarak hazır değilse nazar ve istidlale dayanmalıdır. Peki nazar ve istidlal özel metafizik varlı̆̆ın bilgisini verir mi?

\section{(b) Nazarın Özel Metafizik Mevcudun Varlığının Bilgisini Genel Olarak Vermesi}

Râzîye göre nazar illetten malûle, eşitten eşite ve malûlden illete şeklinde yürütülebilir bir yöntemdir; ancak metafizikte bunlardan sadece malûlden illete giden yol geçerlidir. Malûlden illete giden bir araştırma ise yaratıcının kendisi, hakikati ve mahiyeti hakkında bilgi vermez. Çünkü malûlden illete giden yol metafizikte genel olarak (alâ sebîli'l-icmâl) sadece varlık bilgisi verir. Malûlden illete giden yolun ayrıntılı bir şekilde (alâ sebîli't-tafsîl) zat bilgisi değil, genel olarak varlık bilgisi verdiği, biri ontolojiden diğeri epistemolojiden alınmış iki ilkeyle gösterilebilir:

Birincisi: Tür olarak malûlün farklı illetleri olabilir. ${ }^{21} \mathrm{Bu}$ öncelikle malûlün illetin türünden olmaması, ikinci olarak da malûlün bilgisinin illetin türünü bize bildirmediği anlamına gelir. O halde malûlden illete giden bir yöntem tür veya mahiyet bilgisi değil, ancak varlık bilgisi verir. Bu çıkarıma örnekler üzerinden biraz daha yakından bakabiliriz: Bir tabiatın ya da gücün tek bir fiili vardır; ancak tür bakımından tek bir fiilin türce farklı illetleri olabilir. Çünkü zaman ve mekân birliği dikkate alınmaksızın bir hakikatin meydana gelmesi, farklı sebeplere dayanabilir. Örneğin mülkiyet alışveriş, hibe, vasiyet veya veraset yoluyla meydana gelebilir. Yine örneğin biz insandaki fiillerden hareketle insandaki farklı güçlerin varlığına hükmedebiliriz. İnsanda büyüme, beslenme, üreme, idrak ve hareket gibi fiillerin varlığı bu fiillere kaynaklık eden ilkenin varlığını gösterir; ancak o ilkenin mahiyetini göstermez. Yine örneğin sıcaklıktan hareketle onun bir sebebine ve sebebin varlığına gidebiliriz; ancak bu ilkenin mahiyeti, yani ısıtan ateş mi, güneş ışığı mı, harekete dayalı bir sürtünme mi olduğu ancak ilkenin mahiyetine yönelik ilave bir araştırmayla bilinebilir. Ayrıca Râzîye göre farklı fiiller, buradaki illetin bir ya da birden fazla olup olmadığı hakkında da bilgi vermeyebilir. Çünkü Râzî, felsefî "Birden ancak bir çıkar" ilkesini ${ }^{22}$ kabul etmediği için, tikel ve tümel idrakler gibi farklı fiillerin nefsin farkl güçlerinden değil, tek bir nefisten çıktığını ileri sürer. Benzer bir örnek insanın zatını şuuru üzerinden

\footnotetext{
21 Râzî, Şerhu Uyûni'l-hikme, nşr. Ahmed Hicâzî es-Sekkâ (Tahran: Müessesetü’s-Sâdıkli't-tıbaa ve'n-neşr, 1415), II, 273.

22 Râzî̀ye göre İbn Sînâ "Birden bir çıkar” ilkesini sadece ay-üstü âlemde değil, fizik ve psikolojide de geçerli kabul etmektedir.
} 
de ifade edilebilir. Şöyle ki İbn Sînâ hem uçan insan tahayyülünden hem nefsin idrak ve düşünme gibi fiillerinden hareketle insan mahiyetinin mücerret olduğunu iddia eder. ${ }^{23}$ Râzî ise fiillerin ve eserlerin mahiyet bilgisi vermeyip varlık bilgisi verdiğinden hareketle şöyle söyler: "Nefsin bir şey olması bakımından varlığının bilgisi bir şeydir; onun ayrıntılı ve belirli bir tarzda ne olduğunun, yani mahiyetinin bilgisi başka bir şeydir." ${ }^{24}$ Şimdi nefsin mahiyetinin "mütehayyiz olmayan ve mütehayyize yerleşmeyen" anlamiyla mücerret olduğunu söylesek bile, mücerretlik olumsuz bir kayıttan ibaret olacaktır ve olumsuz bir kayıt, özel zat (mahiyet) bilgisi vermez. Bu olumsuz sıfatın sadece bir mahiyetin faslı ya da lazımı olduğu itirazı da doğru değildir; çünkü olumsuz bir kaydın bir mahiyetin lazımı olduğunu söylemek mümkün görünmemektedir. O halde nefsin kendi kendisini şuuru yoluyla huzurî olarak bildiğimiz ya da nefsin fiillerinden hareketle bildiğimiz şey, sadece nefsin varlığıdır, mahiyeti değildir. ${ }^{25}$ Bütün bu örneklerden anlaşılacağı üzere sonuç olarak bir fiil olarak âlem, bir sebebin ve yaratıcının varlığının bilgisini verir; ancak o sebebin mahiyeti ve hakikatinin bilgisini vermez. Dahası bu âlemin yaratıcısının nihai yaratıcı olup olmadığının dahi bilgisini vermez ki, bu konu aşağıda ele alınacaktır.

İkincisi: Tasdik ister illet ister varlik bilgisi versin, tasavvur bilgisi vermez. Zira tasdik, iki tarafının, yani konu ve yükleminin künhüyle tasavvuruna bağlı değildir. Şöyle ki biz uzaktaki bir karaltının mahiyetini bilmeksizin onun hakkında "hareketlidir" yüklemesi yapabiliriz. Bu durumda konusu yaratıcı olan bir önermenin konunun hakikati hakkında bilgi vermesi gerekmez. Özetle "Yaratıcı vardır, birdir ve bilendir" şeklindeki önermeler, yaratıcının hakikati hakkında bilgi vermez. Bu tür tasdikleri çoğaltarak O'nun hakkında belli bir resim sunmak teknik anlamıyla mantıktaki resm olacaktır, yoksa mahiyetin künhünü veren bir tanım ve tasavvur olmayacaktır. ${ }^{26}$

Nazarın metafizik hakkında mahiyet bilgisi değil de varlık bilgisi verdiğini ise "Her hâdisin bir muhdisi vardır. / Âlem hâdistir. / O halde âlemin bir muhdisi vardır" şeklindeki hudûs delili üzerinden örnekleyebiliriz. Bu kıyasta orta terim, büyük terimin küçük terimdeki varlığının malûlüdür. Dış dünyada herhangi bir şeyin hâdis olmasının sebebi o şeyin muhdise sahip olmasıdır. Oysa bu kıyas, muhdisin sonucu olan hâdisi, muhdisin âlemdeki varlığını ispatlamaya aracı yapmıştır. Bu kıyasta orta 1978), 126; İbn Sînâ, et-Ta'likkât, haz. Abdurrahman Bedevî (Kum: Mektebetü'l-i'lâmi'l-İslâmî, 1984), 160-1.

24 Râzî, el-Metâlib, VII, 39.

25 Râzî, el-Metâlib, VII, 41, 42.

26 Tasdikin, tarafların künhüyle tasavvuruna bağlı olup olmaması hakkında bk. Eşref Altaş, "Varlık Kavramının Bedâhetine Delil Getirilebilir mi? Müteahhirîn Dönemi Merkezli Bir Tartışma”, İslâm Araştırmaları Dergisi 30 (2013): 59-79. 
terim, büyük terimin küçük terime yüklenmesinin varlıkta değil, zihinde ve hükümde tasdik edilmesinin sebebidir. Bu nedenle de varlık bilgisi verir.

\section{(c) Nazarın Metafizik Alanda Verdiği Varlık Bilgisinin Yakînîliği}

Nazarın metafizik alanda varlık bilgisi verdiğini belirttikten sonra bu bilginin yakînî bir bilgi olduğunu tartışmanın şöyle bir arka planı vardır: Râzî, insan aklının fizik ve metafizik hakkında ancak "en iyi açıklama" tarzında (el-evlâ ve'l-ahlâk) bir bilgi elde edebileceğini sık sık dile getirir. Acaba nazarın herhangi bir ispat yöntemiyle verdiği bilgi de mi "en iyi açıklama" tarzındadır? Burada "en iyi açıklama" diye ifade ettiğimiz el-evlâ ifadesi, Râzînin kendi ifadesiyle epistemolojik açıdan yargı içermeyen baskın bir zannı ifade eder. Böyle bir inanç ise "epistemolojik anlamda yargı içeren bir inanç" dahi değildir; kaldı ki bu tarz bir inanç üzerine eklenen teslimiyet, tasdik, inkıyat, sükûn ve itminanla birlikte bir "dinî inanç" olabilsin. Dolayısıyla bu noktada şöyle bir soru sorabiliriz: Nazarın metafizik alanda verdiği bilgi zannî midir, yakînî midir?

Râzî̀ye göre bir bilginin yakînî olmasının üç şartı vardır: Birincisi A’nın B olduğuna inanç; ikincisi A’nın B olduğu hakkında ilk inancın inanılana mutabık olduğuna ve ona mutabık olmamasının imkânsız olduğu hakkında ikinci bir inanç ve üçüncüsü de bu inançların gerekçesiz olamayacağıdır. Bu gerekçe eğer önerme bedîhî ise tarafların salt tasavvurudur, değilse orta terimdir. Mantıkta dile getirilen bu şartlar Râzîye göre kelâmcıların dilinde şöyle ifade edilmiştir: Yakînî bilgi, hakkında şüpheler ileri sürüldüğünde sahibinin şüpheye düşmediği bilgidir. Bununla da bir şeyin şöyle olduğuna inanmak ve bu inancın, inandığı şeyin zıddına olmasının imkânsız olduğuna inanmak kastedilmektedir. ${ }^{27}$

Şimdi nazarın verdiği bütün bilgilerin böyle bir bilgi olduğunu söyleyebilir miyiz? Râzî̀ye göre bazı nazarî delillerin, öncüllerine bağlı olarak zan verdiği konusunda bir tartışma yoktur. Nazarın matematikte, şüphe ve ihtimallerden uzak bir yarg1 (elcezm) ve tam bir yakîn verdiğini akıllı kimseler tartışmaz. Tartışma yukarıda ifade edildiği gibi fizik ve metafizik alanda böyle bir bilginin mümkün olup olmadığıdır. Râzî’ye göre nazarın metafizikte yargı içeren ve kesin olan bir bilgi verdiği kesindir. Bu görüşü savunanların farklı delilleri varsa da, ${ }^{28}$ Râzîye göre bu konuda dayanılması gereken delil şudur:

Metafiziksel bir mesele ortaya çıktığında ve bu mesele hakkında terkibi ve öncülleri bedîhî olan bir delil tertip edildiğinde ve böylece bu kıyas, sonucu zorunlu kıldığında biz

28 Burada ele almadığımız bu deliller ve eleştirileri için bk. Râzî, el-Metâlib, el-Mantık, vr. 52b-54b. 
"Nazar, metafizikte en az bir bilgi verir" şeklinde tikel bir hüküm elde ederiz. Örneğin "Her hâdisin bir müessiri vardır. / Feleklerin hareketi hâdistir. / O halde feleklerin hareketlerinin bir müessiri vardır" kıyasını ele alalım. Bu kıyasın küçük ve büyük öncülleri zarûriyyâttan olduğunda sonuç zorunludur. O halde küçük ve büyük öncülü inceleyelim:

Malûlden illete giden bu kıyasın küçük öncülü şöyle ispatlanır: Hareket bir halden bir hale intikaldir. Hareketteki bir hali başka bir hal öncelediğinden hareket hâdistir. Buradaki her bir hali, kendi yokluğu önceler. Hâdis, yokluğu varlığını önceleyen şey olduğuna göre bunların toplamı olan hareket de hâdistir.

"Her hâdisin bir müessiri vardır" şeklindeki büyük öncülün nasıl ispat edileceği ise oldukça tartışmalıdır. Öncelikle hem hudûs hem imkân delilinin dayandığı ilke, fail ve fiil arasında kabul edilen temel nedenlilik ya da failiyyettir. ${ }^{29}$ En iradeci teorilerden en akılcı teorilere kadar, bütün İslam düşünce gelenekleri fail ve fiil arasındaki failiyyetin varlığını inkâr etmenin fail ve yaratıcının varlığına giden ispat kapılarının kapanması anlamına geleceğini belirtir. Mutlak iradeci ekollere göre fail bir irade, fiile ya da terke yönelmesini sağlayan bir tercih sebebi (ed-devâî, es-savârıf) olmaksızın fiil yapar ya da terk eder; ancak hiçbir fiil, bir fail olmaksızın ortaya çıkamaz. Nitekim Râzî̀ye göre bir fiilin hiçbir fail olmaksızın ortaya çıktığını savunmak, Yunan atomcuları ve Dehrîler gibi kendiliğindenliği ve rastlantısallığı savunmak anlamına gelir. ${ }^{30}$

"Hiçbir fiil, bir fail olmaksızın ortaya çıkamaz" şeklindeki failiyyet ilkesinin, zorunlu varlığı ispat delillerinin büyük öncülünde nasıl tezahür ettiği ise tartışmanın döndüğü noktadır. İmkân delilinde bu öncül, "Mümkünün iki tarafından birinin diğerine müreccihsiz ağır basması imkânsızdır" ya da "Mümkün, varlığı ve yokluğu için bir illete muhtaçtır" şeklinde ifade edilirken, hudûs delilinde ise "Her hâdis bir müessire muhtaçtır" şeklinde ifade edilir. ${ }^{31}$ İmkân delili konumuz olmadığından şimdilik o bir tarafa bırakılabilir. Hudûs delilinde hudûsun illete ihtiyacı ya da "Her hâdisin bir müessiri vardır" şeklindeki büyük öncülün ispatı ise savunulan hudûs deliline göre farklılık gösterir. Burada Râzînnin eserlerinden hareketle büyük öncülü ispat noktasında -tüketici olmamak kaydıyla- en az üç farklı hudûs delili tespit edebiliriz.

“Büyük öncülü bedîhî olan salt hudûs delili” Ka‘bî ve küçük bir grubun kabul ettiği bir delildir. Bu görüşe göre akıllı her insan bir hâdisi algılar algılamaz onun muhdisine gitmektedir; ki bu da her hâdisin bir muhdisinin bedîhî olarak bilindiğini

31 Bu ilkenin bedîhî mi yoksa istidlâlî mi olduğu tartışması için bk. Râzî, el-Metâlib, I, 74-90; 200-214; Fahreddin er-Râzî, el-Halkve'l-ba's, Süleymaniye Kütüphanesi, Ayasofya 2257, vr. 59a-62b. 
gösterir. Ancak Râzîye göre akıl, her hâdisin sadece onunla eş zamanlı bir muhdisine hükmeder, yoksa doğrudan ezelden beri var olan bir muhdise hükmetmez. Üstelik akıl bir hâdisin zaman ve maddesi olması gerektiğine de hükmeder, oysa ne Ka'bî ne de diğer kelâmcılar ilk yaratılış için zaman ve maddenin gerekliliğini düşünmezler ve bunu düşünen filozofları da eleştirirler. Bu da demektir ki "Her hâdisin bir muhdisi vardır" öncülünde Ka 'bînnin söylediği gibi bir bedâhet iddiası doğru değildir. ${ }^{32}$

"Büyük öncülü müktesep olan salt hudûs delili" ise Ebû Ali, Ebû Hâşim, Kâdî Abdülcebbâr ve bunların takipçileri tarafından kabul edilmektedir. Bu görüşe göre hudûs delili gaibin şahide kıyası olarak formüle edilmiştir. Bu kıyasta asıl, kulun kendi fiilini ihdas eden olmasıdır; fer' âlemdir; hüküm muhdise ihtiyaç duymaktır; illet ise hudûstur. ${ }^{33}$ Ancak bu gaibin şahide kıyası birkaç açıdan problemlidir: İlk olarak Mu'tezilî bir ilkeye, yani kulun fiilini ihdas etmesine dayanmaktadır; yani benim fiilim nasıl benim varlığımı gösteriyorsa âlem de bir fiil olarak kendi yaratıcısını gösterir. Ancak kulun kendi fiilini ihdas ettiği herkes tarafından kabul edilebilir ve ispat edilebilir bir ilke değildir. Bu da demektir ki, gaibe yüklenen hükmün şahitte bir temeli yoktur. İkincisi burada, yani bu dünyada hâdisin faile muhtaç olduğu hükmü, gaibe, yani metafiziğe taşınmıştır. Ancak böyle bir kıyasın geçerli olabilmesi için, kıyasın gaib ile şahit arasında illet, hakikat, şart ve istidlal birliğini bir araya getirmesi, yani câmi' olması gerekir. Ancak Tanrı ile hâdis olan kul arasında bir başka ifadeyle Tanrı ile onun dışındakiler arasında mutlak bir ontolojik mübayenet olduğundan, bu kıyasta yukarıdaki birlik türlerinin sağlanması mümkün değildir ya da iddia edilen birliğin gerçekte bir birlik olup olmadığından emin olunamaz. Diğer ifadeyle bu delili ileri sürenler nezdinde, Tanrı'dan -kendiyle özdeş olmamak, kendinden bütünüyle de farklı olmamak kaydıyla- varlığın taşması tarzında bir sudûr düşüncesi kabul edilmediğinden Tanrı ile âlem arasında bir benzerlik (sympatheia, sinhiyyet), mertebe, derece ya da derece derece yükselen eş anlamlllık (teşkîkiyyet) gibi yakınlıklar kurulamaz. Bu durumda hudûs delili, şahit (fizik) dünyasında geçerli olanın -ontolojik mübayenet sebebiyle- gaipte (metafizik) geçerli olup olmadığı hakkında hiçbir bilgi temeline dayanmadığ için bizi bir sonuca götüremez. Eğer hudûs bir yoktan yaratma ise ki öyledir, zaten yoktan yaratma düşüncesi, Tanrı'nın kadim olması ve âlemin hâdis olması sebebiyle Tanrı'nın hakikatinin bütünüyle farklı olduğunu iddia eder ki, böylece kıyas imkânı da ortadan kalkar. ${ }^{34}$

34 Râzî, Nihâyetü'l-ukûl, I, 133-6; Râzî, el-Metâlib, I, 210-4; Ömer Türker, “Bir Tümdengelim Olarak Şâhitle Gâibe İstidlâl Yöntemi ve Cüveynînnin Bu Yönteme Yönelttiği Eleștiriler, İslâm Araştırmaları Dergisi 18 (2007): 12, 16, 23-4. 
O halde Râzîye göre "yaratıcı vardır” demenin imkânı ve zemini nedir? Bir başka ifadeyle ispat delilinde kendisine dayanılacak büyük öncül nasıl ispatlanacaktır?

Bu soru bizi üçüncü tür hudûs deliline, yani Râzînin hudûs deliline götürmektedir. Bu da büyük öncülü "imkân/cevaz" fikri üzerinden ispat edilen ya da imkânı ihtiyacın kaynağı olarak kabul eden hudûs delilidir. Râzî̀nin kendi ifadesiyle "imkânı hudûsa katan delil"dir. En genel olarak bu delili şöyle ifade etmemiz mümkündür:

Zatı gereği mümkün olan her şeyin zorunlu bir faili vardır.

Her hâdis zatı gereği mümkündür.

O halde her hâdisin zorunlu bir faili vardır.

Bu delilin tam olması için belirsiz bir mümkünün, tek tek mümkünlerin, mümkünlerin bir kısmının veya mümkünler toplamının belirsiz bir mümkünü, tek tek mümkünleri, mümkünlerin bir kısmını ya da mümkünler toplamını teselsülen ya da kısırdöngü yoluyla yaratmasının iptali de bir ara öncül olarak konulmalıdır. Bu öncülden sonra Râzî, bu delilde bazen büyük öncülün bedîhî olduğunu söylese de çoğunlukla hâdisin faile ihtiyacının kaynağının imkân olduğunu belirtir. Bu yöntemde cisimlerin/hâdislerin mümkün varlık olduklarına cisimlerin/hâdislerin gözlemden hareketle değişime tabi olmalarıyla delil getirilmekte, sonra da mümkünlerin faile muhtaç olduklarına onların imkânıyla delil getirilmektedir. ${ }^{35}$

Şimdi küçük ve büyük öncül ispat edilmiş zorunlu önermeler ya da bedîhî önermeler olduğunda ve terkipleri mantığın sonuç veren şekil ve darplarından birine uygun olarak tamam olduğunda, kısaca söyleyecek olursak kıyas sureti ve maddesi ile ilgili bütün şartları taşıdığında "Râzînnin epistemolojik anlayışına göre” bu kıyasın sonucu aklen zorunludur. ${ }^{36}$ "Râzî̀nin epistemolojik anlayışı" derken onun kıyasın hazırlama (i'dâd), adet ya da tevellüt teorisiyle değil, zorunluluk yoluyla bilgi verdiğini savunduğunu kastediyoruz. Buna göre bir kıyasın zorunlu bir bilgi vermesi için kısaca şu dört şart gereklidir: (i) Kıyasın öncülleri doğrudan yakînî olmalı ya da önce bulunduğu hal üzere devam etmesinin ve bundan önce bulunduğu hal üzere devam etmemesinin caizliği” şeklindeki bir anlamı kasteder. Bu imkân tanımı bilahare yaratıcının nasıl bir yaratıcı olduğu, varlığın ondan zorunlulukla mı taştığı ya da onun tarafından tahsis edilerek mi yaratıldığı konusunda temel bir işlev kazanır. Çünkü imkânın bu cevaz anlamı, belli bir atomsal grubun belirli özelliklerle şöyle değil de böyle tezahür etmesinin dayandığı zemini tabiatın dışına çıkarır; dolayısıyla temelde yaratıcının sıfatları ve özellikleri konusunda bir delildir. Özeli ispat eden bir delil, genel özelin parçası olduğundan geneli de ispat edeceğinden diğer yönüyle metafiziğe açılan kapılardan biri (bâbü isbâti vâcibi’l-vücûd) olarak da görülebilir.

36 Râzî, el-Metâlib, el-Mantık, vr. 54b; Râzînnin bilgide zorunluluk iddiasının ayrıntıları için şu teze bakılabilir. Ayşe Kaya, "Fahreddîn er-Râzî’nin Bilgide Zorunluluk Teorisi" (Yüksek lisans tezi, Marmara Üniversitesi Sosyal Bilimler Enstitüsü, 2019). 
dolaylı bir şekilde yakînî olanların gerektirdiği bir yakînî olmalı. (ii) Bu mukaddimeler, doğruluğu bedîhî olarak bilinen bir şekilde terkip edilmeli. (iii) Bu mukaddimelerin bu şekilde tertibi, mutabakatı bedîhî olarak bilinen bir şekilde netice vermeli. (iv) Bedîhînin gerektirdiği bilginin bedîhî olduğu bedîhî olarak bilinmeli. ${ }^{37}$ Sonuç olarak ne zaman ki ispat edilmiş küçük öncüle bir büyük öncül eklenirse ve bu büyük öncül de ya bedîhî kabul edilir ya da kesin olarak ispat edilirse, teselsül ve kısırdöngü de bâtıl olduğundan "Her hâdisin bir faili vardır" sonucu kıyasın teknik şartlarının da yerine getirilmesiyle Râzîyye göre zorunlu olarak ortaya çlkar.

Buraya kadar Râzîye göre genel metafizik alanın varlığı, yaratıcı özel bir mevcudun varlığı ve bu mevcudun varlığının bilgisinin yakînîliği üzerinde durduk. Şimdi şu sorulabilir: Acaba genel olarak nazar ve özel olarak hudûs delili, ispat ettiğimiz bu yaratıcının nihai yaratıcı olduğunu, kadim olduğunu, Tanrı olduğunu, dahası ispat ettiğimiz özel metafizik mevcudun hakikati ve mahiyetini verebilir mi? Bu konu başlı başına ele alınmayı hak etse de Râzîye göre "Âlem hâdistir. / Her hâdisin bir muhdisi vardır. / O halde âlemin muhdisi vardır” şeklindeki klasik hudûs delili, ispat ettiğimiz bu yaratıcının ara bir varlık değil de nihai bir varlık olduğunu vermez. Nitekim Râzî hudûs delilinin ancak teselsül ve kısırdöngünün iptali ve Tanrı'nın kadim varlık olduğunun ispatı ile tamamlanabileceğini belirtir. ${ }^{38}$ Ancak yine de Râzî kelâmcıların kadim varlığı ispatlarının her kadimin Tanrı olması gerekmediği ilkesi sebebiyle eleştirilere açık olduğunu dile getiriri. ${ }^{39}$ Ancak bu konu başlı başına ele alınmayı gerektiren uzun bir mesele olduğundan bu makalenin sınırları dışındadır.

\section{III. Özel Metafizik Varlığın Ayrıntılı (Tafsîlî) Bilgisinin İmkânı}

Râzî genel metafizik bir alanı, bir yaratıcıyı, bu yaratıcının nihai varlık olduğunu ve bunun kadim ve zatı gereği zorunlu varlık olan Tanrı olduğunu söylediğine göre şimdi şunu sorabiliriz: Akıl, Tanrı'nın ne ise o olması bakımından zatını bilebilir mi ve bu soruya verilen cevap nasil yorumlanabilir?

\section{(a) Tanrı'nın Özel Zatı (Zât-1 Mahsûsa) Bilinebilir mi?}

Râzî Tanrı'nın özel zatını, mahiyetini, hakikatini (ez-zâtü'l-mahsûsa) bilme hususunda üç farklı gruptan söz eder: (i) Tanrı'nın zatının bu dünyada ve ahirette bilinebileceğini iddia edenler, Eş'arî ve Mu'tezile'den zahiri esas alan kelâmcılar- 
$\operatorname{dır}(e z-z a ̂ h i r i y y u ̂ n) .{ }^{40}$ (ii) Tanrı'nın zatının her iki dünyada bilinemeyeceğini iddia edenler sûfîler, Cüveynî ve Gazzâlî'dir. (iii) Bâkıllânî Tanrı'nın zatının bu dünyada bilinemeyeceğini, ahiretteki durumun da açık olmadığını savunurken, Dırâr b. Amr ise ahirette insanın kendisine verilen altıncı bir duyuyla Tanrı'nın zatını bileceğini savunur. ${ }^{41}$ Râzî̀nin kendisi ise ilk eserlerinden biri olan el-İşâre'de Tanrı'nın zatının bilinebileceğini belirtirken, ${ }^{42}$ el-Levâmi"de Ebü'l-Berekât'ın Tanrı'nın insanın kalbini, kendi zatının bilgisiyle aydınlatabileceğiyle ilgili açıklamasını güzel bulur. ${ }^{43}$

"Zât-ı mahsûsa bilinebilir" iddiasının delilleri ve eleştirisi Râzî tarafından ayrıntılarıyla verilir: Râzîye göre özel zatın bilindiğini iddia edenler beş delil ileri sürebilir: Birinci delil negatif teolojinin kendi içindeki çelişkisini esas alır. Örneğin "Tanrı'nın özel zatı bilinemez” önermesi, kendisiyle çelişik bir şekilde, Tanrı'nın özel zatı hakkında en azından "bilinemeyeceğine dair" bir bilgiyi içerir. Râzî, el-Metâlib, II, 95; Negatif teolojiye yönelik çelişiklik eleştirisi için bk. Michael Durrant, “The Meaning of 'God'-I”, Royal Institute of Philosophy Supplement 31 (1992): 74. İkinci delil pozitif teolojinin Tanrı'ya varlık, birlik, zorunluluk gibi yüklemelerin zatla ilgili olumlu bilgiler verdiğini esas alır. Buna göre bir sıfatın bir zata yüklenmesi ancak zat ve sıfat hakkında bir bilgiden sonra gerçekleşebilir. Bu durumda bir kimsenin zatın bilinemeyeceğine dair negatif teoloji iddiası kendi içinde çelişiktir. Ayrıca zatın bilinemeyeceği iddiası, Tanrı'nın özelliklerini, mesela birliğini bilmekle ve buna inanmakla sorumlu tutan dinlerle de çelişiktir. Üçüncü delile göre eğer biz Allah'ı bir şey olarak biliyorsak bu ya zatı ya sıfatı ya da zata dayanması bakımından sıfatı bilmektir. Tanrı'nın bir şey olarak bilinmesi, mutlak sıfat bilgisi değildir. Bunun eğer zat bilgisi olduğu söylenirse istenen budur. Eğer bunun, zata dayanması bakımından sıfatı bilmek olduğu söylenirse bu da ikinci delildeki kurallar gereği yine zat hakkında bir bilgidir. Dördüncü delil ise Tanrı'nın "kendisiyle kaim bir zat” olduğu hakkındaki bilgimizin ne anlama geldiğinin tahliline dayanır. Buna göre "kendisiyle kaim zat" ya Tanrı'nın mahiyetinin tamamı ya parçası ya da onun dışındadır. Son ihtimal bu sıfatın Tanrı dışında başka bir şeye yüklenmesini gerektirdiğinden; parçası olması şıkkı ise ilahî basitliğe aykırı olduğundan ilk şık geçerlidir. O halde kendisiyle kaim zat bilgisi, Tanrı bilgisidir. Beşinci delile göre Tanrı'nın varlığının bilgisi mahiyetinin bilgisini de verir ki Râzîye göre bu delil, erken dönem kelâmcılarının varlık-mahiyet arasında bir ayrım yapmamasına dayanır. Râzî ilk iki delile karşı eleştirilerini, "Tasavvur olunmayan hakkında hüküm vermek mümkün değildir” önermesinin tahliline dayandırır. Çünkü ilk iki delil doğru kabul edilirse ya bu önermenin öznesinin hakikatinde bir dönüşme (el-inkılâb fi'l-hakîka) gerekecektir. Yani "tasavvur edilmeyen" kavramı, "tasavvur edilen" olarak düşünülecek ve bu da bir şeyin kendisiyle aynı olduğunu ifade eden özdeşlik ilkesini ihlal edecektir. Ya da önerme, öz-gönderim paradokslarından birine (paradoxes of self-reference) girecektir. Râzînin üçüncü ve dördüncü delile karşı eleştirisi de tek ilkeden hareket eder. Buna göre insanın Tanríyı bilmesi, "onun başkasına muhtaç olmayan bağımsız bir zat” olduğunun bilmesidir ki bu da selbî bir ifadedir. Selbî bir ifade, mahiyetin parçası olmadığından, Tanrı'nın hakikati hakkında bilgi vermez. Bu deliller için bk. Râzî, el-Metâlib, II, 96-98; Râzî, Nihâyetü’l-ukûl, III, 211; Râzî, el-Muhassal, 164-5; Fahreddin er-Râzî, el-Erbaîn fì usûlidd-dîn, nşr. Ahmed Hicâzî es-Sekkâ (Kahire: Mektebetü'l-Külliyyâti'l-Ezheriyye, 1415/1986), I, 310. Tanrı'nın özellikleri hakkında olumlu cümlelerin zat hakkında bilgi verdiği iddiasına karşı ise Râzî öncelikle "zat" ve "sıfat" ayrımını, ikincileyin ise "zat hakkında konuşma" ile "zatı bilme" ayrımını esas alarak cevap verir. Negatif teolojinin ılımlı ve radikal türleri bağlamında Tanrı hakkında konuşabilme ve konuşamama ayrımı, Tanrı'yı bilebilme ve bilememe ayrımı için bk. Joseph A. Buijs, “The Negative Theology of Maimonides and Aquinas", The Review of Metaphysics 41/4 (1988): 726.

41 Râzî, Nihâyetü'l-ukûl, III, 210-1; Râzî, el-Muhassal, 164; Râzî öncesi kelâm geleneğinde konuyla ilgili görüşler için bk. Binyamin Abrahamov, "Fahr al-dīn al-Rāzī on the Knowability of God's Essence and Attributes", Arabica 49/2(2002): 204-11.

42 Muhammed Sâlih ez-Zerkân, Fahreddîn er-Râzî ve ârâuhü'l-kelâmiye ve'l-felsefiyye (Kahire: Dâru'l-Fikr, 1963), 205.

43 Fahreddin er-Râzî, Levâmiu'l-beyyinât, nşr. Tâhâ Abdürraûf Sa'd (Beyrut: Dâru'l-Kitâbi'l-Arabî, 1984), 72-3. Aynı eserde Râzî Tanrı'nın hakikatinin künhünün bilinemeyeceğini de belirtir (s. 246). 
Ancak el-Mebâhis, el-Mülahhas, el-Muhassal, el-Erba'în, el-Me'âlim, et-Tefsîru'l-kebîr, el-Metâlib ve daha birçok eserinde bazı küçük farklarla birlikte "Tanrı'nın hakikatinin bilinemeyeceğini” savunduğunu görürüz. Şimdi burada onun bu iddiasını nasıl temellendirdiğine yakından bakabiliriz:

“Tanrı'nın özel zatını bilmek mümkün değildir” önermesini savunan gruplar, Râzîye göre, bu sonuca kendi yöntemlerine özgü delillerle ulaşmaktadırlar. Râzî, Tanr'nın zatının bilinemeyeceğinde rol oynayan (i) epistemolojik zorlukları filozoflar üzerinden, (ii) insana ait ontolojik ve metodolojik sinırlllı̆̆ sûfîler ve mühendisiyyûn üzerinden; (iii) Tanrı'nın ontolojik mübayenetinden kaynaklanan zorlukları ise kelâmcilar üzerinden anlatır. ${ }^{44}$

(i) Epistemolojik zorluklar: Râzî, filozofların, “Tanrı'nın zatı bilinemez" iddiasını üç temele dayandırdıklarını anlatır: Birincisi: Tanrı'nın hakikatini bilseydik, filozofların "İlletin bilgisine sahip olan malûlün bilgisine da sahip olur" kuralı gereği bütün varlıkların bilgisine sahip olmamız gerekirdi. ${ }^{45}$ İkincisi: Filozoflara göre bilgi, bilinenin suretinin bilende meydana gelmesi olarak tanımlandığına göre, Tanrı'nın zatını bilmek, insanın zihninde onun zatının bir suretinin olmasını gerektirecekti. Üçüncüsü: Filozoflara göre, ancak çokların ortaklığına engel olmayan tümelin bilgisi olur, ortaklığa engel olan Tanrı'nın zatı gibi belirli (el-muayyen) bir zatın bilgisinden söz edemeyiz. ${ }^{46}$

Râzî zât-ı mahsûsanın bilinemeyeceğiyle ilgili iddiaya katılmaktadır; ancak filozofların bu delillerinin, bilginin suret olması, illeti bilenin malumu bileceği ve Tanrı'nın mûcib bi'z-zât olduğu gibi felsefî ilkelere dayandığı için yetersiz olduğunu belirtmektedir. Râzîyye göre bütün kayıtlardan mücerret olan Tanr'nın bilinemeyeceği iddiası, felsefî tavırda tutarlı bir şekilde savunulamayacak bir iddiadır; çünkü bilgi, filozoflara göre tam da maddeden mücerret varlık demektir. ${ }^{47}$

44 “Tanrı'da varlık-mahiyet ayrımı yapılabilir mi yapılamaz mı?” tartışmasının bizim konumuz açısından önemi yoktur. Tanrı'da varlık-mahiyet ayrımı hakkındaki tartışma, çoğunlukla sanıldığı gibi, genel varlık (el-vücûdü'l-mutlak) ile Tanrı'nın zatının aynı olup olmadığı değil, Tanrı'nın özel varlığının mahiyetinin aynı olup olmadığıdır. İbn Sînâ’ya göre “Tanrı’ya teşkîkle yüklenen mutlak ve genel varlık (el-vücûdü’l-mutlak) bilinir, ancak Tanrı'nın hüviyeti olan özel varlığı (el-vücûdü'l-hass) bilinemez." (Mahmûd b. Abdurrahman el-İsfahânî, Tesdîdü'l-kavâid fi şerhi Tecrîdi'l-akâid, thk. Eşref Altaş, Muhammed Ali Koca, Salih Günaydın, Muhammed Yetim, İstanbul: Türkiye Diyanet Vakfı İslam Araştırmaları Merkezi (İSAM), 2020. 55. psj.). Sonuç olarak kelâmî literatürde zât-ı mahsûsayı bilme meselesi ile İbn Sînâcı literatürdeki vücûd-ı hassı bilme meselesi herhangi bir ayrıma gidilmeksizin doğru bir şekilde Râzî tarafından aynı başlık altında ele alınmıştır.

45 Râzî, Nihâyetü'l-ukûl, III, 213; Râzî, el-Metâlib, II, 92; Fahreddin er-Râzî, er-Risâletü'l-Kemâliyye fi'l-hakâiki'l-ilâhiyye, nşr. Ali Muhyiddin (Beyrut: Dâru'l-Kütübi'l-ilmiyye, 2002), 47.

46 Râzî, Nihâyetü'l-ukûl, III, 214-6; Fahreddin er-Râzî, el-Mülahhas, Süleymaniye Kütüphanesi, Şehid Ali Paşa 1730, vr. 182a-b; Râzî, el-Metâlib, II, 92-4.

47 Râzî, Nihâyetü'l-ukûl, III, 213-216. 
Râzî̀nin filozoflar açısından meseleyi çoğunlukla epistemolojik anlayışın ürettiği zorluklara binaen anlatması ilginç görünmektedir. Çünkü İbn Sînâ, Tanrı'nın zatının bilinememesini onun ontolojik basitliğine dayandırır. ${ }^{48}$ Bununla birlikte bazı eserlerinde, Râzî̀nin, Tanrı'nın bileşik olmaması, cinsi ve faslı olmaması gibi basitlik ilkesinden hareketle tanımının yapılamayacağı, dolayısıyla mahiyetinin bilinemeyeceği akıl yürütmesini eleştiri yöneltmeksizin kullandığını söylemek gerekir. ${ }^{49}$

(ii) Insana ait ontolojik ve metodolojik kısıtlılıklar: Râzî Tanrı'nın zatının bilinemeyeceğiyle ilgili insanî kısıtlılıkları, sûfîler ve mühendisiyyûn üzerinden ifade eder. Çünkü İslam düşünce tarihinde nazara dayalı metafiziğin imkânına yönelik en radikal eleştiriler sûfîler ve mühendisiyyûn tarafından dile getirilmiştir. Burada iki temel delil vardır: Birinci delile göre Tanrı sınırsız, insan sınırlıdır. Sinırlı olan, sinırsız olanı ihata edemez. ${ }^{50}$ Hiçbir duyunun sınırını aşamadığı gibi aklın da makuller sınırını aşamayacağı hakkındaki delilleri de bu çerçevede değerlendirmek mümkündür ki, buna göre aklın alanı makuller olup aklın metafizik hakikatleri ve nurları aydınlatması söz konusu değildir. ${ }^{51}$ İkincisi ise bilenin, bilinen üzerinde bir hükümranlığı ve baskınlığının ortaya çıkmasıdır ki, insanın, Tanrı'nın zât-ı mahsûsasını bilmekle bu tür bir baskınlık elde etmesi, zorunlu ve mümkünün tabiatlarına aykırıdır. ${ }^{52}$ Râzînnin metafizik bilginin imkânı, sınırı ve yaygınlığı ile ilgili başka bir delili ise insanlığın, metafizik bilgiler ve ahlâkî pratikler söz konusu olduğunda tek bir tür gibi olmadıkları, farklı türler gibi anlaşılmaları gerektiğidir. Ona göre madenleri içermeleri bakımından dağlar farklı olduğu gibi insanlar da tür türdür. ${ }^{53}$ Râzî, bu görüşüyle, bütün insanlar için eş kapsamlı bir metafizik bilginin ve metafizik inşasının mümkün olmadığına ve metafizik bilgilerin, bilim haline getirilemeyeceği anlamında şahsîliğine dikkat çeker.

Râzî insanın sınırlılığını, metafizik bilgiyi mümkün görmeyen mühendisiyyûn üzerinden farklı üç delille daha pekiştirir. Bunlardan birincisine göre, insan en açık

Rahim Acar, Talking about God and Talking about Creation: Avicenna's and Thomas Aquinas' Positions (Leiden-Boston: Brill, 2005), 26-8.

49 Râzî, el-Metâlib, III, 245-6; Râzî, farklı eserlerinde Hz. Musa ile Firavun arasında geçen tartışmalarda Firavun'un israrla “Âlemlerin rabbi nedir?” (Şuarâ 26/23) şeklindeki mahiyet sorusuna Hz. Musa'nın Allah'ın sıfatları, isimleri ve fiilleriyle cevap verdiğini anlatır. Râzînnin konuyla ilgili Kur'an'dan getirdiği deliller çoktur. bk. Râzî, el-Metâlib, III, 245; Râzî, Tefsîr-i Kebîr, XVII, 312-316 (Şuarâ 26/23. ayetinin tefsiri).

50 Râzî, Nihâyetü'l-ukûl, III, 220; Râzî, el-Metâlib, II, 94; Râzî bu delili, "mütekaddimûn”a atfeder ki, bu ifadeyle muhtemelen Cüveynîyi kastetmektedir. Krş. İmâmü’l-Haremeyn el-Cüveynî, el-Burhân fî usûli'l-fikh, thk. Abdülazîm ed-Dîb, 2. bs. (Kahire: Dâru'l-Ensâr, ty.), I, 142-4.

51 Râzî, el-Metâlib, VII, 283-4.

52 Râzî, Nihâyetü'l-ukûl, III, 220, Râzî, el-Metâlib, II, 94-5. Râzî de "Allah kulları üzerinde kâhirdir." (En'âm 6/61) ayetini yorumlarken, insanın Tanrı'nın zatını bilmesinin ona baskın olmak anlamına geleceğini belirtir. Râzî, Tefsîr-i Kebîr, XVII, 315-6 (Şuara 26/23. ayetinin tefsiri). 
kendisini bilmesine rağmen insanlar, nefis hususunda farklı görüşlere sahiptir. Bu da demektir ki insan kendi nefsi, yine zaman, mekân, cisim, gıdalar, ilaçlar ve kesin bir şekilde ispat edebildiği geometrik bazı nesnelerin mahiyeti hakkında tam bir bilgiye sahip değildir. Diğer ifadeyle insan kendi ontolojik düzleminde bile ancak daha iyi açıklamaları içeren zannî ve tahminî bilgilere (el-evlâ ve'l-ahlâk) sahiptir. Buna kıyasla insanın, kendi tabiatına en uzak varlık olan, kendisinden ve mevcudatın tamamından farklı olan Tanrı'nın zatı hakkında kesinlik içeren bir bilgisinin olmaması tabiidir. ${ }^{54}$ Râzî̀nin bu çerçevede zikrettiği ikinci delil ise nazar yönteminin metafizik bilgi vermedeki sınırlılığına odaklanır. Çünkü biz Tanrı'nın zatı hakkında bilgi elde etmek için ancak (a) illetten malûle giden bir yol, (b) eşitten eşite giden bir analoji ve (c) malûlden illete giden bir yol takip edebiliriz. Burada ilk iki yol, Tanrı'nın zatının bilgisini elde etmek için geçerli yollar olmadığına göre üçüncü yolu takip etmek gerekecektir. Ancak üçüncü yol hem Tanrı'nın ontolojik mübayeneti hem hayal, vehim ve aklın yanıltıcı hükümlerinin hem de mevcudattaki ontolojik katmanların çokluğunun engel teşkil etmesi sebebiyle Tanrı'nın hakikatine ulaştırıcı bir yol olarak görülemez. Bu yolda yolculuk, eğer bir kemal yolculuğu olarak ele alınacak olursa, insan nefsi metafizik soyut varlıkların mertebelerinin en alt katmanında bulunur. Dolayısıyla yolculuk uzundur ve yanıltıcılar çoktur. Bu nedenle insanların çoğu, bu mertebelerin hepsini aşamayıp birinde takılarak en son mertebe olan Tanrı'nın zatına ulaşamaz. Bu yolun başka bir zorluğu şudur: Bir malûl, ancak belirsiz bir illete delalet eder, dolayısıyla âlemdeki fiiller, gerekler ve eserler ancak bir illetin varlığına delalet eder, yoksa illetin mahiyetine delalet etmez. ${ }^{55}$

(iii) Tanrı'nın ontolojik mübayenetinden kaynaklanan zorluklar: Her şeyden önce aynı hakikatler ortak lazımları gerektirir ve zorunlu olan Tanrı'nın mümkünlerle hakikati bakımından eşit olması hem mümkünlerin hem de zorunlunun, mümkün ve zorunlulukta eşitliğini gerektirir ki bu imkânsızdır. ${ }^{56}$ Râzînnin Tanrı'nın ontolojik mübayenetiyle ilgili daha uzun delilleri varsa da burada bununla değil, bu ontolojik mübayenetin bilme problemine nasıl zemin teşkil ettiğiyle ilgileniyoruz. Bu problem etrafında Râzî, kelâmcıların iki delilini zikreder: Birinci delile göre biz, Allah'ın varlığını, varlığının keyfiyetini, olumsuz ve olumlu izafî sıfatları el-Metâlib'in farklı yerlerinde Aristoteles'ten naklettiği şöyle bir ifadeyle pekiştirir: "Aristoteles demiştir ki: 'Metafiziksel bilgilere başlamak isteyen kişi kendisi için başka bir fitrat ihdas etsin.' Onun kastı şudur: İnsan vehim ve hayalin hükümleriyle ülfet halindedir. Vehimler ve hayallerin hükümleri ise metafizik bahislerle uyuşmamaktadır. İşte bu sebeple bu talibe başka bir mizaç icat etmesi gerekmektedir." Râzî, el-Metâlib, I, 57; II, 20; Râzî, Esâsu't-takdîs, 36.

Râzî, el-Mülahhas, 179b; Râzî, el-Muhassal, s. 133; Râzî, el-Erbaîn, I, 137-42; Râzî, er-Risâletü'l-Kemâliyye, 51. 
biliriz. Bunları bilmek zatı bilmek değildir; çünkü varlık bilgisi, illetin mahiyetinin bilgisini vermez. Bunları bilmek zatı bilmeyi gerektirmez; çünkü bu özellikleri bilmek bize orada bu özelliklere sahip olan bir şeyin var olduğu bilgisini verir ama o şeyin mahiyetinin bilgisini vermez. O halde Tanrı'nın zatını bilemeyiz. ${ }^{57}$

Kelâmcıların ikinci delili ise Râzînin görüşünü daha iyi anlamamızı sağlar ve temelde insandaki kavramların kökenine odaklanır. Çünkü Râzîye göre insanda duyu, vicdan, akıl ve terkip şeklindeki dört farklı kaynaktan doğan dört tür bilgi vardır: (a) Beyaz, tiz ses, sertlik, tatlı ve güzel koku gibi duyuların idrakiyle elde ettiğimiz duyusal niteliklerin ve cisim gibi duyusal cevherlerin bilgisi. (b) Acı, güçsüzlük, açlık, arzu, sevgi gibi kendimizde aracısız bulduğumuz vicdanî niteliklerin bilgisi. (c) Varlık, yokluk, birlik, çokluk, zorunluluk, imkân, imkânsızlık gibi aklımızda bulduğumuz ikinci makuller. (d) Bu üç kökenden gelen kavramlarla cıvadan oluşan deniz, Anka ve bin bir başlı kartal gibi hayalin, düşman olan şu kurt gibi vehmin; önerme ve kıyas gibi aklın birleştirdiği birleşik kavram, önerme ve kıyasların verdiği bilgiler. ${ }^{58}$

Şimdi bizzat “Tanrı'nın hakikati”nin bilgisi bu yollardan biriyle elde edilmiş bir bilgi midir? Râzîye göre "ilahın hakikati”, yukarıdaki dört kaynaktan birinden alınamadığı için bilinemez ve esasen bunun altında yatan neden de Tanrı'nın ontolojik farklılığından başka bir şey değildir. Tanrı'nın zatı duyu, vicdan, akıl yoluyla idrak edilen bir şey değildir; çünkü Tanrı'nın zatı bütün yaratılanlardan farklıdır (muhấlefetün li'l-havâdis). Tanrı bu idrak yollarından alınan kavramlardan telif edilen bir şey de değildir; çünkü Tanrı bileşik değildir.

Sonuç olarak felsefî, mistik ve nazarî yolların kendi yöntemlerine göre ürettiği delillerin ortak noktası şudur: Tanrı'nın zatı bilinemez. ${ }^{59}$

\section{(b) Zat-1 mahsûsanın Bilinemeyeceği Görüşünün Semantik Yorumu}

Hemen önceki başlıkta Râzînin, ontolojik mübayenet ilkesine, insanın epistemolojik ve metodolojik sınırlılıklarına dayanarak Tanrı'nın zatının bilinemeyeceğini nasıl savunduğunu tasvir ettik. Bu tasvire göre Râzî, genel olarak, ontolojik mübayenete sahip aşkın Tanrı anlayışıyla, özel olarak ise negatif teolojinin metafizik teziyle

58 Râzî, Nihâyetü'l-ukûl, III, 219-20; Râzî, el-Metâlib, I, 49-50; II, 90-91; Râzî, el-Muhassal, 65; Râzî, el-Erbaîn, I, 309.

59 Konunun bu yönü ve deliller için bk. Mustafa Bozkurt, “Fahreddin er-Râzî̀de Allah'ın Hakikatini Bilmenin İmkânı”, Turkish Studies: Türkoloji Araştırmaları: International Periodical for the Languages, Literature and History of Turkish or Turkic XIII/25 (2018): 129-143. 
(MNT: metaphysical thesis of negative teology) uyumlu bir şekilde şunu söylemektedir: Tanrı'nın zatı, var olmuş, var olan ve var olabilecek her şeyden farklıdır ve "O'nun hiçbir benzeri yoktur" (Şûra süresi, 42/11). Râzî yine, genel olarak bir hadiste "Allah'ın yarattıkları hakkında düşünün, O'nun zatı hakkında düşünmeyin"60 şeklinde ifadesini bulan dinî tavra ve özel olarak negatif teolojinin ontolojik mübayenet ilkesinden doğan epistemolojik tezine (ENT: epistemic thesis of negatif theology) ${ }^{61}$ uygun bir şekilde Tanrı'nın var olduğunu bildiğimizi, ama onun mahiyetini bilemediğimizi belirtmektedir. Ancak Râzînin “Tanrı'nın zatı bilinemez" iddiası, negatif teolojinin farklı versiyonlarının bu sonuca götüren öncüllerine dayanmaz. Dolayısıyla Râzînin zatın hakikatiyle ilgili negatif teolojisi, bir radikal negatif teoloji değildir. ${ }^{62}$

Bu durumda Râzî̀nin, zatla ilgili negatif teolojisinin semantik tezi (SNT: semantic thesis of negatif theology $)^{63}$ nasıl anlaşılmalıdır? Bir başka ifadeyle Râzî̀nin "Tanrı'nın zatı bilinemez" iddiası tam olarak ne anlama gelmektedir? Çünkü bu iddia özel metafizik varlığın inkârı, metafizik şüphecilik, Tanrı hakkında konuşmanın anlamsızlığı, Yeni Platoncu ilahî basitliğin dile getirilemezliği, Tanrı'nın olumlu önermelerde konu olamayacağı ve aklın ilahî olan karşısındaki hayretinin bir ifadesi gibi farklı şekillerde anlaşılabilir. O halde tekrar sormak gerekirse Râzî, "Tanrı'nın zatı bilinemez" ifadesiyle tam olarak neyi kastetmektedir?

“Tanrı'nın zatı bilinemez" şeklindeki epistemolojik tezin nasıl anlaşılması gerektiğini ifade eden sınırlanmış farklı semantik tezler ileri sürebiliriz. Şimdi bu tezlere göre:

[SNT1] "Tanrı'nın zatı bilinemez" demek "Tanrı, sadece olumsuz önermede konu olabilir." demektir. ${ }^{64}$ Bu yorumu Râzînin kabul ettiğini söylemek mümkün değildir; çünkü bu yorum, kısıtlayıcı bir şekilde Tanrı'nın olumlu bir önermede konu olamayacağını söylemektedir. Oysa Râzî hem Tanr'nın hem onun icâbî, selbî ve fiilî sıfatlarının ister olumlu olsun ister olumsuz olsun yüklemin konusu yapılabileceğini belirtir ki, örneğin "Tanrı âlimdir” önermesi böyledir.

Ebû Bekir Ahmed b. el-Hüseyin el-Beyhâkî, el-Esmâ ve's-sıfât (Beyrut: Dâru'l-Kütübi'l-i̇lmiyye, 1984), 360 .

61 Buijs, "The Negative Theology", 727.

62 Örneğin Pseudo-Dionysos’a ait NT’nin dört önermesi Rojek tarafından şöyle ifade edilebilir: Tanrı tüm olumlu özelliklere sahiptir. Tanrı tüm olumlu özelliklerin olumsuzluklarına sahiptir. Tanrı, olumlu özelliklerin tüm olumsuzluklarının olumsuzluklarına sahiptir. Tanrı bilinemez. bk. Pawel Rojek, "Towards a Logic of Negative Theology”, Logic in Religious Discourse, ed. A. Schumann (Frankfurt: Ontos Verlag, 2010), 194-7.

63 Buijs, "The Negative Theology", 727.

64 Buijs, "The Negative Theology", 727. 
[SNT2] “Tanrı'nın zatı bilinemez" demek "Tanrı hakkında sadece ne olmadığ söylenerek konuşulabilir” demektir. ${ }^{65}$ Bu yorum ise temelde Tanrı'nın yalnızca zatı hakkında, tanımlayıcı bir ifade olmamak kaydıyla "ne olmadığını" söyleyerek konuşabileceğimizi iddia etmektedir. Ancak Râzî, tanımlayıcı bir ifade olmamak kaydıyla, Tanrı hakkında "cisim değildir", "âlimdir", "bilgisiz değildir", "ezelidir" şeklinde yükleme yapmaktadır ki, bu yüklemelerden birincisi formu ve anlamılla olumsuz, ikincisi formu ve anlamıyla olumlu, üçüncüsü formu olumsuz anlamı olumlu ve dördüncüsü formu olumlu ama anlamı olumsuzdur.

Râzînin [SNT1] ve [SNT2]'ye karşı iki örneğine burada işaret edebiliriz: Birinci örneğe göre Tanrı'nın zatını bilemesek de onun hakkında olumlu konuşma imkânımız vardır. Çünkü bizdeki şekli ve miktarıyla biz kendimizde yetkinlik (kemâl) ve eksiklik anlamını düşündüğümüzde zorunlu olarak mutlak anlamdaki yetkinlik ve eksiklik anlamını da anlarız. Çünkü mutlak, kayıtlanmış mahiyetin bir parçasıdır. Yani özel olarak kendimizin yetkinliğini ve eksikliğini düşünmek, ancak mutlak manadaki yetkinliği ve eksikliği düşünmekle mümkündür. Böylece bu mutlak yetkinlik anlamını, bizde bulunması sebebiyle bu anlama ilişen eksikliklerden temizlemek şartıyla, Tanrı'ya olumlu olarak yüklenebileceğini kabul ederiz. Sonuçta "Tanrı mükemmeldir" dememiz mümkün olur. ${ }^{66}$ Yine Tanrı'nın zatını bilmesek de eksiklikleri ondan nefyetmek şartıyla Tanrı hakkında olumsuz cümlelerle konuşabiliriz. Örneğin "Tanrı'nın ortağının bulunması imkânsızdır" önermesini ele alalım: $\mathrm{Bu}$ önerme, duyudan gelen "ortak" kavramı, akıldan gelen "imkânsız" kavramı ve yine genel olarak bilinen "Tanrı" kavramlarının akıl tarafından birleştirilmesinden ibarettir. Akıl önce iki kavramı birleştirerek "Tanrı'nın ortağı” kavramını oluşturmuş, ardından "Tanrı'nın ortağı" kavramının imkânsızlığını ortaya koymak için insanın durumuna kıyas etmiş ve insanda bulunan anlamın Tanrı hakkında geçerli olmadığına hükmetmiştir. ${ }^{67}$

[SNT3] "Tanrı'nın zatı bilinemez" demek "Tanrı hakkında kesinlikle konuşulamaz" demektir. İlk iki semantik yoruma karşı Râzînnin geliştirdiği tutum dikkate alınırsa Râzînin tezinin "Tanrı hakkında kesinlikle konuşulamaz" şeklinde "sessizliğin teolojisi" olarak da anlaşılamayacağı ortaya çıkar. Çünkü bu yoruma göre Tanrı müteâldir ve insan dili sınırlıdır; bu nedenle Tanrı hakkında olumlu ya da olumsuz her türlü yüklemeden kaçınılmalıdır; insan, Tanrı hakkında sessiz kalmalı ve konuşmamalıdır. Oysa Râzî için bunun tersi gösterilmişti. Ayrıca Râzî muhtelif yerlerde dile getirdiği 
gibi, "Tanrı hakkında konuşulamaz" ifadesinin ya kavramsal çelişiklik ya da öz-gönderim paradokslarından birini (paradoxes of self-reference) içerdiğini söyleyecektir. ${ }^{68}$

[SNT4] “Tanrı'nın zatı bilinemez” demek, inançsızlık anlamına gelir. Ateist ya da sofistik bir yorum olan bu yorumu da Râzînin kabul ettiğini söylemek mümkün değildir. Çünkü yukarıda belirtildiği üzere Tanrı'nın bütün mevcutlardan başka olduğunu (muhâlefetün li'l-havâdis) ifade eden bir metafizik teze dayanan "Tanrı'nın zatı bilinemez" iddiası, onun var olmadığı anlamına gelmez. Bunun açık bir sebebi vardır: Yukarıda ele alındığı üzere mahiyeti vermeyen, ama varlığı veren deliller oluşturmak mümkündür. Daha iyi bir delil şu olabilir: Mümkün mevcutlardan bütünüyle farklı bir şeyin var olduğunu söylemek mümkündür. Çünkü bir şeyin kendine özgü nitelikleriyle bütün mümkün mevcutlardan tamamen farklı olması, onun yokluğunu mantıksal olarak gerektirmez. Bir başka ifadeyle Tanrı'nın benzerinin yokluğu, onun zatının yokluğunu gerektirmez. Esasen herhangi bir şeyin varlığının, benzerinin varlığına bağlı olduğunu söylemek doğru değildir; çünkü herhangi bir şeyin varlığı ile benzerinin varlığı arasında bir korelasyon yoktur. Ayrıca bireylik (et-teşahhus / et-teferrüd) ve dışta belirme (et-taayyün) bir şeyin benzerlerinden temeyyüzüyle gerçekleşir; bu da demektir ki benzerlik değil, benzememezlik (muhâlefet) ve ayrışma (et-temeyyüz) daha fazla bireyliği ve dışta tekilliği sağlayan bir şeydir. ${ }^{69}$ Sonuç olarak zatın bilinemez olması, zatın yokluğunu göstermez.

[SNT5] Zatın bilinemezliği Tanrı'nın zatı hakkında bir agnostisizmi ifade edebileceği gibi ${ }^{70}$ Tanrı'nın varlığı hakkında hükümsüzlük içeren bir agnostisizm olarak da anlaşılabilir. Bu yorum, "olumlu önermeye konu olamaz" şeklindeki [SNT1]'deki mantıksal vurguyu ve "konuşulamaz" şeklindeki [SNT3]'deki dilsel vurguyu, "bilinemez" şeklindeki epistemolojik bir vurguya kaydırır. Yine [SNT3] dinî teslimiyeti artıran bir yorum iken "özellikle zatın varlığının bilinemezliğı" şeklindeki agnostik bir yaklaşım olan [SNT5], dinsel inancı ortadan kaldıran bir yorumdur. ${ }^{71}$ Râzîye göre Tanrı'nın zatının bilinemez olmasının Tanrı'nın varlığı hakkında bir agnostisizm olarak anlaşılması doğru değildir. Yukarıda ayrıntılı olarak ele alındığı üzere zat hakkında bir agnostisizmin zatın varlığı hakkındaki bir agnostisizme dönüştürülmesi, zatın bilinmesi ile varlığının bilinmesi arasındaki farkı kavrayamamaktan kaynaklanmaktadır. Râzî̀den Taşköprülüzâde’ye 'Mutlak Meçhul' Paradoksu”, Nazariyat 6/1 (Nisan 2020), 85-207.

69 Râzî, Allah'in Aşkınlığı, s. 37-38; Râzî, el-Metâlib, II, 23-4.

70 Cüveynî hakkında böyle bir yorum için bk. Ömer Türker, "Eş‘arî Kelâmının Kırılma Noktası: Cüveynînnin Yöntem Eleştirileri”, İslâm Araştırmaları Dergisi 19 (2008): 16-7.

71 Rojek, “Towards a Logic”, 201-5; Piotr Urbańczyk, “The Logical Challenge of Negative Theology”, Studies in Logic, Grammar and Rhetoric 54/1 (2018): 158-63. 
[SNT6] Zatın bilinemezliği, müteâl bir varlık karşısında dinî teslimiyetin ifadesi olarak da yorumlanabilir. Bu yorumla Tanrı'nın zatının bilinemez ve hakkında konuşulamaz olması agnostisizmi değil, dinî teslimiyeti, tevazuyu, mahviyeti ve hayreti gerektirir. Kutsallığın temel nüktesi ve derin anlamı da zaten budur. Bu sebeple birçok dinsel gelenek Tanrı adını söylemeyi yasaklar ve yasaklanmışlık (muharrem) kutsallığın derin boyutlarından biridir. Bu sebeple Râzî metinlerinin zât-ı mahsûsanın bilinemezliğini tartışan bölümleri, Tanrı'nın aşkınlığı, celali, azameti ve kibriyası ile bu azametin karşısında insanın acziyet, hayret ve dehşet gibi mahviyet ve teslimiyet ifade eden duyguları arasındaki gerilime güçlü vurgular yapar:

[İnsan için ürkütücü düğümlerden birisi] zatın bilgisidir. Eğer biz, Allah'ın zatının duyularımızla algıladığımız, içimizde bulduğumuz (vicdân) ve aklımızla düşündüğümüz herhangi bir şeye eşit olduğuna hükmedersek O’nun zatının mümkün olması gerekir. Oysa bu imkânsızdır. Eğer o özel zatın, düşündüğümüz ve bildiğimiz bütün mevcutlardan farklı olduğuna hükmedersek bu durumda akıl, hiçbir şeye ulaşamamış olarak hayret içerisinde ve şaşkın bir halde kalır. Bundan çıkan sonuç şudur: Akıl, o özel hakikati, ona idrakinin ulaştığı bir tarzda ispat etmişse onu tanımamış demektir. Çünkü aklın idrak edebildiği her şey mümkün varlıktır, zorunlu varlık değildir. Akıl o özel hakikati, bu hakikatlerinden farklı olacak şekilde ispat etmişse bu sefer de onu ne ise o olması bakımından bilememiş demektir. Onu bilmeye ve tasavvur etmeye güç yetirememişse onu celal, azamet ve kutsal sıfatlarla nitelemesi nasıl mümkün olacaktır? İşte bu, zatı bilmek konusunda heybetli bir durak / heybet veren bir duraksamadir." ${ }^{\text {2 }}$

Sonuç olarak Râzînnin “Tanrı'nın zatı bilinemez” görüşü, "hakkında konuşulamaz” şeklinde suskunluğu gerektiren bir yoruma tabi tutulamaz; Tanrı'nın varlığının inkârını gerektirmez; Tanrı'nın varlığı hakkında hükümsüzlüğü gerektiren bir yoruma tabi tutulamaz; dinî pratik hayatı ortadan da kaldırmaz. Râzînnin bu görüşü, epistemolojik bir vurguyu barındırır. Buna göre Tanrı'nın zatı ve hakikati bilinemez, ulaşılamaz ve kavranılamazdır. Ancak O'nun hakkında olumlu ya da olumsuz yükleme yapılabilir, sıfatları, fiilleri ve özellikleri hakkında konuşulabilir. Bu da künhü hakkında bilgimiz olmasa da Tanrı hakkında varlık gibi farklı yönlerden bilgiye sahip olduğumuz ve konuşabildiğimiz anlamına gelir [buna SNT7 diyelim].

Burada son olarak şunu sormak gerekir: Negatif teolojinin metafizik, epistemolojik ve semantik tezleri, kendi aralarında bir gereklilik (lüzûm) ilişkisine sahip midir? Bir başka ifadeyle Tanrı'nın selbî ve sübûtî sıfatları, isimleri ve fiilleri hakkında konuşmak ve bunların bilindiğini iddia etmek “Tanrı bilinir” anlamına gelmez mi? 
Tersinden söylersek bu kadar Tanrı hakkında konuşup da "Tanrı'nın zatı bilinemez" demek bir çelişki değil midir? ${ }^{73}$

Râzî Tanrı'nın varlığını, sıfatlarını, isimlerini ve fiillerini bilmek ile Tanrı'nın zatını bilmek arasında bir gereklilik ilişkisinin (mülâzemet) bulunmadığını belirtmektedir. Öncelikle mahiyet bilgisinin yokluğu, mahiyetin yokluğunu gerektirmediği gibi, bir mahiyetin varlığının bilgisi de mahiyetin künhünü bilmeyi gerektirmez. Çünkü Tanrı'nın hâdis, mümkün ve mütehayyiz olmadığını bilmek ve bir mahalle hulûl etmediğini bilmek, ayrıca onun bilen, kâdir gibi sübûtî ssfatlara sahip olduğunu bilmek bize ancak hakikatin lazımlarını verir. Bunların ifade edilmesi de ancak bir hakikatin lazımları ile tarifini verebilir. Mantık kuralları gereği bir şeyin lazımlarının bilinmesi, onun ne ise o olması açısından bilinmesini gerektirmez. ${ }^{74}$

Bu kuralı amacımıza uygun bir şekilde biraz daha ayrıntılı olarak ele alabiliriz: (i) Varlığı bilmek zatı bilmek değildir; çünkü genel varlık ile Tanrı́nın özel varlığı başkadır. (ii) Tanrı'nın zorunlu olduğu bilgisi de mahiyet bilgisi değildir; çünkü zorunluluk Tanrı'nın varlığının bir özelliğidir; zorunluluk bilgisi onun varlığının kendinden olmasını, varlığının devamlılığını, muhtaçsızlığını, yokluğunun imkânsızlığını ve nihai tahlilde her bakımdan basitliğini gösterir, ${ }^{75}$ ki bunların tamamı Tanrı'nın varlığının özelliklerini bilmekten başka bir şey değildir. Bir başka ifadeyle zorunlu ifadesi, "vardır" yükleminin modalitesi olarak anlaşıldığında, ancak Tanrı'nın varlık tarzını bildirir, yoksa mahiyetini değil. (iii) Tanrı'nın olumsuz niteliklerini bilmek ise ancak Tanrı'nın ne olmadığını bilmek olduğundan onun zatının doğrudan bir bilgisini vermez. (iv) İzafî sıfatları bilmek ise zat ile başkası arasında bir izafet olduğundan zatın kendisini bilmek değildir. (v) Râzîye göre zat-sıfat her bakımdan özdeş olmadığı için, hakikî sıfatları bilmek de zât-ı mahsûsayı bilmek değildir. Özetle Râzîye göre biz kendimizde, içimizde ve vicdanımızda, mahiyetini bilmediğimiz ancak bu beş özellikle nitelendiğini bildiğimiz bir şeyi bulabiliriz. Bu da bu beş özelliği bilmenin mahiyeti bilmek olmadığının delillerinden biridir. ${ }^{76}$

Râzî̀ye göre gerekliliğin olmadığını gösteren delillerden biri de şudur: Sonucun varlığından sebebin varlığının bilgisine gitmek, sebebin mahiyeti hakkında bilgi vermez; bir şeyin mahiyetini, sadece kavramsal olarak bilmek mümkündür ve yine bir şeyi

Bu lüzum farklı bir bağlamda Hayner tarafından da dile getirilmiştir. Buna göre Tanrı'nın hakikatini ifade eden olumsuz ifadeler, doğruluklarının test edildiği bir noktadan, Tanrı'nın hakikatinin bilindiğini varsayıyor görünmektedir. Paul C. Hayner, "Analogical Predication", The Journal of Philosophy 55/20 (1958): 859.

74 Râzî, el-Mülahhas, vr. 182a-b; Râzî, el-Metâlibü'l-âliye: el-Mantık, 31b.

75 Râzî, el-Metâlib, III, 247-8.

76 Râzî, el-Metâlib, II, 89-90; Râzî, er-Risâletü'l-Kemâliyye, 47. 
doğrudan tecrübe ederek bilmek mümkündür. Şimdi biz âlemin mümkün olduğunu, her mümkünün bir sebebi olduğunu bildiğimizde, kısırdöngü ve teselsülün de yanlışlığını bildiğimizde bu öncüllerden mümkünlerin zorunlu varlığa dayandırılması gerektiğini çıkarırız. İşte bu, kendisinin başkasına dayanmadığı ama başkasının kendisine dayandığ1 bir varlığın ispatıdır. Bu ispatta mutlak varlık bilgisi, başkasının ona dayandığına dair izafet bilgisi ve onun başkasına dayanmadığına dair selbî bir bilgi vardır. Bunların hiçbiri zât-1 mahsûsa olmadığı gibi, yine hiçbirinin bilgisi de zât-1 mahsûsanın bilgisi değildir. ${ }^{77}$

Gerekliliğin olmadığını gösteren delillerden biri de yukarıda geçtiği üzere tasdikin taraflarının mahiyetini bildirmediğidir. Kısaca konusu Tanrı olan bir önermenin Tanrı'nın hakikati hakkında bilgi vermesi gerekmez. Çünkü tasdik, iki tarafının künhüyle tasavvuruna bağlı değildir. Dolayısıyla “Tanrı bilendir” şeklindeki bir önermenin Tanrı'nın hakikati hakkında bilgi vermesi zorunlu değildir. ${ }^{78}$

Selbî ya da tenzihî dil, bir yandan Tanrínın cisim olarak kabul edilmesi (tecsîm) ve insana benzetilmesi (teşbîh) gibi antropomorfik yaklaşımlara karşı geliştirilmişken, diğer taraftan insan aklının kibrini, insanın her şeyi ve metafizik alanı mantıksal tanımlarla bilebileceği, hatta Tanrı'nın zatının bilineceği fikrini sorgulamayı mümkün kılmıştır. Râzî'nin aklın sınırlarını çizen bu negatif teolojisi İslam düşünce tarihinde mistisizme, temsile ve şiire dayalı anlatının, mantıksal olarak kanıtlanmayan ancak dinî tecrübeyle üretilen bilgilerin kapısının ardına kadar açılmasını ve meşruiyet sınırından geçmesini mümkün kılmıştır. el-Metâlib’in Tanrı'nın zatını bilmenin imkânsızlığı hakkındaki ikinci faslını, üçüncü faslın "riyâzet ve mücâhede yolunun değeri"ni ele alan konusuyla takip etmesi tesadüf değildir. ${ }^{79}$ Bununla birlikte Râzînin zatın bilinmesiyle ilgili negatif tutumu, metafizik alanın tamamına uygulanabilecek radikal bir tutum değildir. Çünkü Râzî zât-ı mahsûsa hakkında değilse de zatın olumlu ve olumsuz sıfatları hakkında bilgi elde edebileceğimizi söyler. Bu durumda sorumuz “Tanrı'nın sıfatları, isimleri ve fiilleri hakkında neyi bilebiliriz?” şekline dönüşür. Bir başka ifadeyle nazar yoluyla ayrıntılı bir tarzda (alâ sebîli't-tafsîl) özel metafizik varlığın bilgisi mümkün müdür? Râzî işte bu noktada, "en iyi açıklama" diye ifade ettiğimiz bir "evleviyet metafiziği”ni öne çıkarır, ki bu sorular ve cevapları başka bir çalışmanın konusudur. 


\section{Sonuç}

Aklın metafizik bir bilgiye ulaşmasının mümkün olup olmadığı İslam düşüncesindeki temel tartışmalardan biridir. Râzî bu soruyu bir yandan metafizik malumları zat, varlık, sıfat, isim ve fiil bilgisi gibi ayrımlarla diğer yandan ise metafiziğin icmâlî bilgisi ve tafsîlî bilgisi ayrımları yaparak cevaplamaya çalışır. Dolayısıyla Râzî bu soruya, ele alınan metafizik maluma bağlı olarak olumlu veya olumsuz cevap verir.

Râzî genel olarak metafizik alanın ispatını, duyularla elde edilenlerin belirlenmesi ve sınırlanmasının duyuyu aşmasına dayandırır. Bunun delili, duyulur nesnenin duyuda inşa edilememesidir. Ayrıca duyulur olanın ötesindeki tümel de metafizik alanın ispatını sağlar. Nesnenin bir şey olarak tahakkukunu sağlayan hakikatinin soyutluğu, bu hakikatin kaynağının da soyutluğunu verir.

Râzî nazarın genel metafizik alanı ispat edebildiği gibi özel metafizik varlığı da ispat edeceğini belirtir. Çünkü Tanr'nın varlığı, Râzîye göre zorunluluk, taklit, kalbin tasfiyesi, duyular, ilham, masum imam öğretisi gibi yollarla bilinemez. Tanrı'nın varlığının bilinmesi için illetten malûle ve eşitten eşite giden bir nazarî faaliyet yürütülemeyeceği için de geriye nazarî faaliyet olarak sadece malûlden illete giden bir yol kalır. Sonuçtan sebebe giden bu yol ise metafizik alanın varlığı hakkında bilgi verir. Nazarî yolun, yani kıyasın maddî ve sûrî şartları sağlandığı durumda da metafizik varlık bilgisini veren deliller, bize aklen zorunlu bir bilgi verir. Sonuç olarak Râzîye göre metafizik alanın bilgisini, Tanrı'nın varlığının bilgisini elde etmek imkânsız değildir. Ancak ârızî şartlar sebebiyle zor olduğu söylenebilir.

Râzî̀ye göre, Tanrı'nın ontolojik mübayeneti ve insanın epistemolojik bakımdan sınırlılığı sebebiyle insan Tanrı́nın zatını bilemez. Bu nedenle Râzî mühendisiyyûn grubunun metafizik bilginin imkânına yönelik eleştirilerinin, sadece Tanrı'nın zatının bilinmemesi konusunda geçerliliğini kabul eder.

Râzî̀nin zatla ilgili "bilinemez" şeklindeki negatif teolojisinin ontolojik tezini “Tanrı'nın zatı her şeyden farklıdır" şeklinde, epistemolojik tezini ise “Tanrı'nın var olduğunu bilebiliriz; ancak hakikatini bilemeyiz" şeklinde ifade edebiliriz. Ancak Tanrı'nın zatını bilememek, Râzîye göre onun hakkında sadece olumsuz cümlelerle konuşabileceğimiz, hiçbir olumlu yükleme yapamayacağımız anlamına gelmediği gibi zatın bilinememesi ateist ya da agnostik bir yoruma da tabi tutulamaz. Zatı bilememek ancak Tanrı'nın azameti karşısında insanda hayret duygusunu geliştirir, mahviyet ve teslimiyeti besler.

Râzînnin zaman zaman zor, zaman zaman evleviyet olarak nitelediği Tanrı'nın isim, sıfat ve fiilleri hakkında bir bilgiye sahip olup olamayacağımız ve böyle bir bilgiye sahip olabilirsek hangi tarzda sahip olacağımız tartışması ise başka bir çalışmanın konusudur. 


\section{Kaynakça}

Abrahamov, Binyamin, "Fahr al-dīn al-Rāzī on the Knowability of God's Essence and Attributes", Arabica 49/2 (2002), 204-30.

Acar, Rahim, Talking about God and Talking about Creation: Avicenna's and Thomas Aquinas' Positions, Leiden-Boston: Brill, 2005.

Ahmed b. Hanbel, er-Red 'ale'l-Cehmiyye ve'z-Zenâdika, thk. Sabrî Selâme Şahin, Riyad: Dâru's-Sebât, 1424.

Altaş, Eşref, "Varlık Kavramının Bedâhetine Delil Getirilebilir mi? Müteahhirîn Dönemi Merkezli Bir Tartışma”, İslâm Araştırmaları Dergisi 30 (2013), 59-79.

el-Beyhâkî, Ebû Bekir Ahmed b. el-Hüseyin, el-Esmâ ve’s-sıfât, Beyrut: Dâru'l-Kütübi'l-İlmiyye, 1984.

Bozkurt, Mustafa, "Fahreddin er-Râzîde Allah'in Hakikatini Bilmenin İmkânı”, Turkish Studies: Türkoloji Araştırmaları: International Periodical for the Languages, Literature and History of Turkish or Turkic XIII/25 (2018), 129-143

Buijs, Joseph A., “The Negative Theology of Maimonides and Aquinas”, The Review of Metaphysics 41/4 (1988), 723-38.

Bulhof N. ve L. Kate, "Echoes of an Embarrassment Philosophical Perspectives on Negative Theology: An Introduction", Flight of the Gods: Philosophical Perspectives on Negative Theology, ed. Ilse N. Bulhof ve Laurens ten Kate, New York: Fordham University Press, 2000.

el-Cüveynî, İmâmü'l-Haremeyn, el-Burhân fì usûli'l-fikh, thk. Abdülazîm ed-Dîb, 2. bs., Kahire: Dâru'l-Ensâr, ty. Durrant, Michael, “The Meaning of 'God'-I”, Royal Institute of Philosophy Supplement 31 (1992), 71-84.

Fazlıoğlu, İhsan, “Râzî Krizini Aşmak: Mevlânâ’nın ‘Arayış'1 İçin Yeni Bir Yorum”, Düşünen Şehir 8 (2019), 104-17.

Hayner, Paul C., “Analogical Predication”, The Journal of Philosophy 55/20 (1958), 855-862.

Ibn Sînâ, el-Işârât ve't-tenbîhât, Fahreddin er-Râzî, Şerhu'l-Işârât ve't-tenbîhât, thk. Ali Rıza Necefzâde, Tahran: Encümen-i Âsâr ve Mefâhir-i Ferhengî, 1384 içinde.

--------, el-Mübâhasât, haz. Abdurrahman Bedevî, Aristo inde'l-Arab içinde, Kuveyt: Vekâletü'l-Matbûât, 1978.

Ibn Sînâ, et-Ta'lîkât, haz. Abdurrahman Bedevî, Kum: Mektebetü'l-i'lâmi’l-Islâmî, 1984.

el-İsfahânî, Mahmûd b. Abdurrahman, Tesdîdü'l-kavâid fi şerhi Tecrîdi'l-akâid, thk. Eşref Altaş, Muhammed Ali Koca, Salih Günaydın, Muhammed Yetim, İstanbul: Türkiye Diyanet Vakfı İslam Araştırmaları Merkezi, 2020.

Kaplan, Hayri, "Bahâ Veled, Şems ve Mevlânâ’nın Râzî’ye Eleştirileri ve Râzînnin Sûfîlere/Tasavvufa Bakışı”, Tasavvuf İlmî ve Akademik Araştırma Dergisi 6/14 (2005), 285-330.

el-Kâtibî, Necmettin Ali b. Ömer, el-Mufassal, thk. Abdülcabbâr Ebû Senîne, Amman: el-Asleyn li'd-dirâsât ve'n-neşr, 2018/1439.

Kaya, Ayşe, "Fahreddîn er-Râzînnin Bilgide Zorunluluk Teorisi”, Yüksek lisans tezi, Marmara Üniversitesi Sosyal Bilimler Enstitüsü, 2019.

Kuşlu, Harun, “Bilinemeyeni Bilmek: Fahreddin Râzîden Taşköprülüzâde’ye 'Mutlak Meçhul' Paradoksu”, 
Nazariyat 6/1 (Nisan 2020), 85-107.

Mevlânâ, Celâlüddîn Muhammed b. Muhammed el-Belhî, Mesnevî, çev. Veled İzbudak, İstanbul: MEB Yayınlar1, 1988, V.

er-Râzî, Fahreddin, Allah'ın Aşkınlığı: Esâsu't-takdîs fî ilmi'l-kelâm, çev. İbrahim Coşkun, İstanbul: Iz Yayıncıllı, 2006.

--, el-Erbaîn fî usûli'd-dîn, nşr. Ahmed Hicâzî es-Sekkâ, Kahire: Mektebetü'l-Külliyyâti'l-Ezheriyye, $1415 / 1986$.

----_---, el-Halk ve’l-ba's, Süleymaniye Kütüphanesi, Ayasofya 2257.

--------, el-Meâlim fî usûli'd-dîn, thk. Tâhâ Abdürraûf Sa'd, Kahire: Mektebetü'l-Külliyâti'l-Ezheriyye, ts.

, el-Metâlibü'l-âliye mine'l-ilmi'l-ilâhî, thk. Ahmed Hicâzî es-Sekkâ, Beyrut: Dâru'l-Kitâbi'l-Arabî, $1407 / 1987$

--------, el-Metâlibü'l-âliye: el-Mantık, Süleymaniye Kütüphanesi, Fatih. 3145.

----_---, el-Mülahhas, Süleymaniye Kütüphanesi, Şehid Ali Paşa 1730.

--------, er-Risâletü'l-Kemâliyye fi'l-hakâiki'l-ilâhiyye, nşr. Ali Muhyiddin, Beyrut: Dâru'l-Kütübi'l-ilmiyye, 2002.

--------, er-Riyâzü'l-mûnika fî ârâi ehli’l-ilm, nşr. Es‘ad Cum‘a, Tunus: Merkezü'n-neşri'l-câmii, 2004.

--------, el-Muhassal: Kelam ve Felsefenin Ana Meseleleri, trc. Eşref Altaş, İstanbul: Klasik Yayınları, 2019

--------, Levâmiu’l-beyyinât, nşr. Tâhâ Abdürraûf Sa‘d, Beyrut: Dâru’l-Kitâbi’l-Arabî, 1984.

----_---, Nihâyetü'l-ukûl fi dirâyeti'l-usûl, thk. Said Abdüllatif Fûde, Beyrut: Dâru'z-Zehâir, 2015/1436.

-----_--, Şerhu Uyûni'l-hikme, I-III, nşr. Ahmed Hicâzî es-Sekkâ, Tahran: Müessesetü's-Sâdıkli't-tıbaa ve'nneşr, 1415.

--------, Şerhu'l-Işârât ve't-tenbîhât, thk. Ali Rıza Necefzâde. Tahran: Encümen-i Âsâr ve Mefâhir-i Ferhengî, 1384.

, Tefsîr-i Kebîr, trc. Cafer Sadık Doğru vd., İstanbul: Huzur Yayınevi, 2013.

Rojek, Pawel, “Towards a Logic of Negative Theology”, Logic in Religious Discourse, ed. A. Schumann, 192-215, Frankfurt: Ontos Verlag, 2010.

Türker, Ömer, “Bir Tümdengelim Olarak Şâhitle Gâibe İstidlâl Yöntemi ve Cüveynînin Bu Yönteme Yönelttiği Eleştiriler, İslâm Araştırmaları Dergisi 18 (2007), 1-25.

, "Eş‘arî Kelâmının Kırılma Noktası: Cüveynînin Yöntem Eleştirileri”, İslâm Araştırmaları Dergisi 19 (2008), 1-24.

Urbańczyk, Piotr, “The Logical Challenge of Negative Theology”, Studies in Logic, Grammar and Rhetoric, 54/1 (2018), 149-174.

ez-Zerkân, Muhammed Sâlih, Fahreddin er-Râzî ve ârâuhü'l-kelâmiye ve'l-felsefiyye, Kahire: Dâru'l-Fikr, 1963. 